\title{
Illumina MiSeq 16S amplicon sequence analysis of bovine respiratory disease associated bacteria in lung and mediastinal lymph node tissue
}

Dayle Johnston ${ }^{1,2}$, Bernadette Earley ${ }^{1}$, Paul Cormican ${ }^{1}$, Gerard Murray ${ }^{3}$, David Anthony Kenny ${ }^{1}$, Sinead Mary Waters', Mark McGee ${ }^{4}$, Alan Kieran Kelly ${ }^{2}$ and Matthew Sean McCabe ${ }^{1 *}$

\begin{abstract}
Background: Bovine respiratory disease (BRD) is caused by growth of single or multiple species of pathogenic bacteria in lung tissue following stress and/or viral infection. Next generation sequencing of 165 ribosomal RNA gene PCR amplicons (NGS 165 amplicon analysis) is a powerful culture-independent open reference method that has recently been used to increase understanding of BRD-associated bacteria in the upper respiratory tract of BRD cattle. However, it has not yet been used to examine the microbiome of the bovine lower respiratory tract. The objective of this study was to use NGS $16 \mathrm{~S}$ amplicon analysis to identify bacteria in post-mortem lung and lymph node tissue samples harvested from fatal BRD cases and clinically healthy animals. Cranial lobe and corresponding mediastinal lymph node post-mortem tissue samples were collected from calves diagnosed as BRD cases by veterinary laboratory pathologists and from clinically healthy calves. NGS 165 amplicon libraries, targeting the V3-V4 region of the bacterial 16S rRNA gene were prepared and sequenced on an Illumina MiSeq. Quantitative insights into microbial ecology (QIIME) was used to determine operational taxonomic units (OTUs) which corresponded to the $16 \mathrm{~S}$ rRNA gene sequences.
\end{abstract}

Results: Leptotrichiaceae, Mycoplasma, Pasteurellaceae, and Fusobacterium were the most abundant OTUs identified in the lungs and lymph nodes of the calves which died from BRD. Leptotrichiaceae, Fusobacterium, Mycoplasma, Trueperella and Bacteroides had greater relative abundances in post-mortem lung samples collected from fatal cases of BRD in dairy calves, compared with clinically healthy calves without lung lesions. Leptotrichiaceae, Mycoplasma and Pasteurellaceae showed higher relative abundances in post-mortem lymph node samples collected from fatal cases of BRD in dairy calves, compared with clinically healthy calves without lung lesions. Two Leptotrichiaceae sequence contigs were subsequently assembled from bacterial DNA-enriched shotgun sequences.

Conclusions: The microbiomes of the cranial lung lobe and mediastinal lymph node from calves which died from BRD and from clinically healthy H-F calves have been characterised. Contigs corresponding to the abundant Leptotrichiaceae OTU were sequenced and found not to be identical to any known bacterial genus. This suggests that we have identified a novel bacterial species associated with BRD.

Keywords: Bovine respiratory disease, lung microbiome, 165 sequencing, diagnostics

\footnotetext{
* Correspondence: matthew.mccabe@teagasc.ie

${ }^{1}$ Animal and Bioscience Research Department, Animal \& Grassland Research

and Innovation Centre, Teagasc Grange, Dunsany, Co. Meath, Ireland

Full list of author information is available at the end of the article
}

(c) The Author(s). 2017 Open Access This article is distributed under the terms of the Creative Commons Attribution 4.0 International License (http://creativecommons.org/licenses/by/4.0/), which permits unrestricted use, distribution, and reproduction in any medium, provided you give appropriate credit to the original author(s) and the source, provide a link to the Creative Commons license, and indicate if changes were made. The Creative Commons Public Domain Dedication waiver (http://creativecommons.org/publicdomain/zero/1.0/) applies to the data made available in this article, unless otherwise stated. 


\section{Background}

Bovine respiratory disease (BRD) is associated with significant morbidity and mortality in cattle worldwide, and contributes to substantial economic losses [1-3]. Clinical signs associated with BRD typically include elevated rectal temperature, increased respiratory rate, nasal and ocular discharges, cough, dyspnea, decreased appetite and depression [2, 4, 5]. In Ireland, BRD is a leading cause of mortality in calves between one and 5 months of age [6].

BRD results from a multifactorial aetiology of infectious agents, host factors, environmental stress factors and their interactions [7-9]. Primary pathogens including bovine herpesvirus 1 (Bo-HV1), bovine respiratory syncytial virus (BRSV), bovine parainfluenza 3 virus (BPIV-3), bovine viral diarrhoea virus (BVDV), bovine coronavirus (BCoV) and Mycoplasma bovis, are thought to be generally responsible for the onset of BRD [1, 4, 10-12] although recent viral metagenomic NGS studies suggest that there are many more uncharacterised BRD-associated viruses than was previously thought $[13,14]$. BRD-associated viral and Mycoplasmal pathogens damage the lungs by causing immunosuppression, ciliary dysfunction and cellular necrosis $[15,16]$. This damage allows proliferation and colonisation by secondary bacterial pathogens, commonly including Mannheimia haemolytica, Pasteurella multocida, Histophilus somni, Mycoplasma bovis and Trueperella pyogenes, which are normally commensal in the nasopharyngeal region of cattle [1, 7, 11, 17-19]. These bacteria evade the lung's remaining immune defences and their virulence factors cause progression of the disease if left untreated $[7,11,15,16]$.

Currently available vaccinations and antibiotic treatments are targeted against the known viruses and bacteria associated with BRD. Poor efficacy of vaccination and antimicrobial treatments against BRD associated bacteria [20-22] may partially be due to the involvement of unknown bacterial pathogens in the disease.

The methods that are currently used for identification of specific bacteria associated with fatal cases of BRD are culture, immunohistochemistry, in-situ hybridisation and multiplex and uniplex polymerase chain reaction (PCR) [23]. However, these techniques are time consuming and they have several limitations. Although culture is considered the gold standard for pathogen identification [24], the main limitation of this technique is that many bacterial species associated with BRD are difficult to culture [25, 26]. PCR has been demonstrated to be a more sensitive method than culture for identification of bacteria in bovine pneumonic lung tissue $[27,28]$. Although real-time qPCR is commonly used in veterinary diagnostic laboratories, only known bacteria can be identified using this "closed reference" technique and each
qPCR assay is generally designed to detect one individual bacterial species.

Next generation sequencing of $16 \mathrm{~S}$ ribosomal RNA gene PCR amplicons (NGS 16S amplicon analysis) has been used for identification of bacteria present in diverse sample types including clinical isolates [29, 30], the bovine rumen [31], human nasal lavage [32] and nasopharyngeal swabs from feedlot cattle [26, 33]. As primers bind to conserved regions of the $16 \mathrm{~S}$ ribosomal RNA (rRNA) gene [34] and phylogenetically variable regions are amplified and subsequently sequenced (typically generating 10,000100,000 sequences per sample), identification of the bacteria present (both known and unknown) in the sample is possible at unprecedented depth [35].

The aim of this study was to use NGS $16 \mathrm{~S}$ amplicon analysis to identify unculturable and previously unknown bacteria which may play a pathogenic role in BRD. For this we analysed DNA from post-mortem cranial lung lobe and mediastinal lymph node tissue from beef and dairy calves with BRD diagnosed as the cause of death, and from clinically healthy Holstein-Friesian (H-F) calves. We found highly abundant $16 \mathrm{~S}$ sequence for which the closest match was Leptotrichiaceae. This putative Leptotrichiaceae $16 \mathrm{~S}$ sequence was present in lung and lymph node tissue from fatal BRD cases and in lung lesions from clinically healthy calves but was absent in lesion-free lungs from clinically healthy calves. To our knowledge this is the first report of detection of this putative Leptotrichiaceae species in bovine lung lesions in cattle with BRD and also the first report of NGS 16S amplicon analysis of lung tissue and lung-associated lymph nodes in cattle with BRD.

\section{Methods}

\section{Post-mortem tissue sample collection}

Thirty-eight cranial lung lobe tissue samples were collected post-mortem from 32 beef calves and 6 dairy calves which were submitted from farms in three different regions in Ireland. Mediastinal lymph node tissue was also collected from 32 of these animals. BRD was diagnosed on gross examination at three regional veterinary laboratories (RVLs) (Athlone, Kilkenny and Sligo) by experienced pathologists. Bacteriological culture, virological and/or bacteriological PCR and histology for identification of aetiological agents (Table 1 and Additional file 1) were performed at the RVLs. In all cases, lung tissue samples were harvested from lesions (lesions were defined as macroscopic consolidation or abscessation of lung tissue) present on the cranial lobes of the lung. Approximately $1 \mathrm{~g}$ of each of these tissues was collected from each calf (comprising 13 beef and dairy breeds) (Table 1). Six of these post-mortem lung tissue samples were frozen at $-80{ }^{\circ} \mathrm{C}$ immediately following collection. The remaining lung and lymph node post-mortem tissue samples were 
Table 1 Description of post-mortem tissue samples collected at RVLs

\begin{tabular}{|c|c|c|c|c|c|c|c|c|c|c|}
\hline Calf ID & $\begin{array}{l}\text { Tissue types } \\
\text { collected }\end{array}$ & $\begin{array}{l}\text { Preservation } \\
\text { method }\end{array}$ & $\begin{array}{l}\text { Age } \\
\text { (months) }\end{array}$ & Sex & Breed & $\begin{array}{l}\text { County of } \\
\text { farm of origin }\end{array}$ & $\begin{array}{l}\text { RVL } \\
\text { location }\end{array}$ & $\begin{array}{l}\text { Lesions } \\
\text { observed }\end{array}$ & Histology & RVL diagnosis \\
\hline 1 & lung & frozen & 6 & $\mathrm{~F}$ & SIX & Donegal & Sligo & $\checkmark$ & $\checkmark$ & Pneumonia (BRSV suspected) \\
\hline 2 & lung & frozen & 1 & M & FRX & Donegal & Sligo & $\checkmark$ & $x$ & Pneumonia and enteritis \\
\hline 3 & lung & frozen & 12 & M & PTX & Donegal & Sligo & $\checkmark$ & $\checkmark$ & Pneumonia - IBR and M. bovis \\
\hline 4 & lung & frozen & 12 & M & $\mathrm{BBX}$ & Donegal & Sligo & $\checkmark$ & $\checkmark$ & Pneumonia - IBR and M. bovis \\
\hline 5 & lung & frozen & 7 & M & $\mathrm{CHX}$ & Donegal & Sligo & $\checkmark$ & $\checkmark$ & Pneumonia - H. somni \\
\hline 6 & lung & frozen & 6 & $\mathrm{~F}$ & $\mathrm{CHX}$ & Leitrim & Sligo & $\checkmark$ & $x$ & $\begin{array}{l}\text { Pneumonia - } M \text {. haemolytica } \\
\text { and BPIV-3 virus }\end{array}$ \\
\hline 7 & $\begin{array}{l}\text { lung and } \\
\text { lymph node }\end{array}$ & frozen & 1 & $\mathrm{~F}$ & LM & Sligo & Sligo & $\checkmark$ & $x$ & $\begin{array}{l}\text { Pneumonia and navel } \\
\text { infection - M. bovis, } \\
\text { Pseudomonas spp. }\end{array}$ \\
\hline 8 & $\begin{array}{l}\text { lung and } \\
\text { lymph node }\end{array}$ & RNALater & 8 & M & $\mathrm{FR}$ & Leitrim & Sligo & $\checkmark$ & $x$ & Pneumonia - T. pyrogenes \\
\hline 9 & $\begin{array}{l}\text { lung and } \\
\text { lymph node }\end{array}$ & RNALater & 0 & M & RBX & Donegal & Sligo & $\checkmark$ & $x$ & $\begin{array}{l}\text { Pneumonia - IBR, H. somni, } \\
\text { T. pyrogenes }\end{array}$ \\
\hline 10 & $\begin{array}{l}\text { lung and } \\
\text { lymph node }\end{array}$ & RNALater & 3.5 & M & FR & Leitrim & Sligo & $\checkmark$ & $x$ & $\begin{array}{l}\text { Pneumonia- } \text { P. multocida and } \\
\text { S. dublin }\end{array}$ \\
\hline 11 & $\begin{array}{l}\text { lung and } \\
\text { lymph node }\end{array}$ & RNALater & 2.5 & $\mathrm{~F}$ & LM & Sligo & Sligo & $\checkmark$ & $x$ & Pneumonia \\
\hline 12 & $\begin{array}{l}\text { lung and } \\
\text { lymph node }\end{array}$ & RNALater & 0 & $\mathrm{~F}$ & $\mathrm{CHX}$ & Carlow & Kilkenny & $\checkmark$ & $x$ & Pneumonia \\
\hline 13 & $\begin{array}{l}\text { lung and } \\
\text { lymph node }\end{array}$ & RNALater & 3 & $\mathrm{~F}$ & AAX & Galway & Athlone & $\checkmark$ & $\checkmark$ & Pneumonia - M. haemolytica \\
\hline 14 & $\begin{array}{l}\text { lung and } \\
\text { lymph node }\end{array}$ & RNALater & 2 & $\mathrm{~F}$ & LMX & Westmeath & Athlone & $\checkmark$ & $\checkmark$ & $\begin{array}{l}\text { Pneumonia and bacteraemia- } \\
\text { P. multocida }\end{array}$ \\
\hline 15 & $\begin{array}{l}\text { lung and } \\
\text { lymph node }\end{array}$ & RNALater & 0 & $\mathrm{~F}$ & AAX & Offaly & Athlone & $\checkmark$ & $\checkmark$ & $\begin{array}{l}\text { Pneumonia - IBR and necrotic } \\
\text { laryngitis }\end{array}$ \\
\hline 16 & $\begin{array}{l}\text { lung and } \\
\text { lymph node }\end{array}$ & RNALater & 0 & $\mathrm{~F}$ & AAX & Offaly & Athlone & $\checkmark$ & $\checkmark$ & $\begin{array}{l}\text { Pneumonia and pleurisy - } \\
\text { Pasteurella spp., IBR and BRSV }\end{array}$ \\
\hline 17 & $\begin{array}{l}\text { lung and } \\
\text { lymph node }\end{array}$ & RNALater & 0 & M & $\mathrm{CHX}$ & Longford & Athlone & $\checkmark$ & $\checkmark$ & $\begin{array}{l}\text { Pneumonia and rotavirus } \\
\text { enteritis }\end{array}$ \\
\hline 18 & $\begin{array}{l}\text { lung and } \\
\text { lymph node }\end{array}$ & RNALater & 1 & M & $\mathrm{CHX}$ & Roscommon & Athlone & $\checkmark$ & $\checkmark$ & $\begin{array}{l}\text { Pneumonia and navel ill - } \\
\text { T. pyogenes (suspected virus } \\
\text { and Pasteurella) }\end{array}$ \\
\hline 19 & $\begin{array}{l}\text { lung and } \\
\text { lymph node }\end{array}$ & RNALater & 0 & M & WAX & Waterford & Kilkenny & $\checkmark$ & $x$ & $\begin{array}{l}\text { Pneumonia and rotavirus } \\
\text { enteritis }\end{array}$ \\
\hline 20 & $\begin{array}{l}\text { lung and } \\
\text { lymph node }\end{array}$ & RNALater & 1.5 & $\mathrm{~F}$ & FR & Tipperary & Kilkenny & $\checkmark$ & $\checkmark$ & $\begin{array}{l}\text { Pneumonia - H. somni and } \\
\text { M. bovis }\end{array}$ \\
\hline 21 & $\begin{array}{l}\text { lung and } \\
\text { lymph node }\end{array}$ & RNALater & 3 & M & LM & Kilkenny & Kilkenny & $\checkmark$ & $\checkmark$ & $\begin{array}{l}\text { Pneumonia - H. somni and } \\
\text { M. bovis }\end{array}$ \\
\hline 22 & $\begin{array}{l}\text { lung and } \\
\text { lymph node }\end{array}$ & RNALater & 0 & $\mathrm{~F}$ & $\mathrm{CHX}$ & Kilkenny & Kilkenny & $\checkmark$ & $\checkmark$ & $\begin{array}{l}\text { Pneumonia - P. multocida / } \\
\text { H. somni bronchopneumonia }\end{array}$ \\
\hline 23 & $\begin{array}{l}\text { lung and } \\
\text { lymph node }\end{array}$ & RNALater & 0 & M & LMX & Laois & Kilkenny & $\checkmark$ & $\checkmark$ & $\begin{array}{l}\text { Pneumonia - H. somni } \\
\text { bronchopneumonia }\end{array}$ \\
\hline 24 & $\begin{array}{l}\text { lung and } \\
\text { lymph node }\end{array}$ & RNALater & 3 & M & LMX & Sligo & Sligo & $\checkmark$ & $x$ & Pneumonia \\
\hline 25 & $\begin{array}{l}\text { lung and } \\
\text { lymph node }\end{array}$ & RNALater & 2 & M & $\mathrm{CH}$ & Mayo & Sligo & $\checkmark$ & $x$ & Pneumonia - Proteus spp. \\
\hline 26 & $\begin{array}{l}\text { lung and } \\
\text { lymph node }\end{array}$ & RNALater & 3 & $\mathrm{~F}$ & $\mathrm{CHX}$ & Leitrim & Sligo & $\checkmark$ & $x$ & $\begin{array}{l}\text { Pneumonia - Endocarditis, } \\
\text { enzootic pneumonia, } \\
\text { inhalation pneumonia }\end{array}$ \\
\hline 27 & $\begin{array}{l}\text { lung and } \\
\text { lymph node }\end{array}$ & RNALater & 1.5 & $\mathrm{~F}$ & LMX & Sligo & Sligo & $\checkmark$ & $x$ & Pneumonia - IBR \\
\hline
\end{tabular}


Table 1 Description of post-mortem tissue samples collected at RVLs (Continued)

\begin{tabular}{|c|c|c|c|c|c|c|c|c|c|c|}
\hline 28 & $\begin{array}{l}\text { lung and } \\
\text { lymph node }\end{array}$ & RNALater & 1.5 & F & AAX & Sligo & Sligo & $\checkmark$ & $x$ & $\begin{array}{l}\text { Pneumonia - IBR and } \\
\text { Proteus spp. }\end{array}$ \\
\hline 29 & $\begin{array}{l}\text { lung and } \\
\text { lymph node }\end{array}$ & RNALater & 12 & M & $\mathrm{CHX}$ & Donegal & Sligo & $\checkmark$ & $\checkmark$ & $\begin{array}{l}\text { Pneumonia - (possible IBR) } \\
\text { and meningitis }\end{array}$ \\
\hline 30 & $\begin{array}{l}\text { lung and } \\
\text { lymph node }\end{array}$ & RNALater & 1 & M & AA & Sligo & Sligo & $\checkmark$ & $x$ & Pneumonia - M. bovis \\
\hline 31 & $\begin{array}{l}\text { lung and } \\
\text { lymph node }\end{array}$ & RNALater & 2.5 & F & LMX & Donegal & Sligo & $\checkmark$ & $x$ & Pneumonia - M. bovis \\
\hline 32 & $\begin{array}{l}\text { lung and } \\
\text { lymph node }\end{array}$ & RNALater & 3 & F & LMX & Kilkenny & Kilkenny & $\checkmark$ & $\checkmark$ & $\begin{array}{l}\text { Pneumonia - interstitial } \\
\text { pneumonia }\end{array}$ \\
\hline 33 & $\begin{array}{l}\text { lung and } \\
\text { lymph node }\end{array}$ & RNALater & 2.5 & M & FR & Laois & Kilkenny & $\checkmark$ & $x$ & Pneumonia - P. multocida \\
\hline 34 & $\begin{array}{l}\text { lung and } \\
\text { lymph node }\end{array}$ & RNALater & 5 & M & AAX & Kilkenny & Kilkenny & $\checkmark$ & $\checkmark$ & $\begin{array}{l}\text { Pneumonia - P. multocida, } \\
\text { T. pyrogenes chronic } \\
\text { bronchopneumonia }\end{array}$ \\
\hline 35 & $\begin{array}{l}\text { lung and } \\
\text { lymph node }\end{array}$ & RNALater & 4.5 & F & LMX & Sligo & Sligo & $\checkmark$ & $\checkmark$ & Pneumonia - Pasteurellosis \\
\hline 36 & $\begin{array}{l}\text { lung and } \\
\text { lymph node }\end{array}$ & RNALater & 1 & M & $\mathrm{CHX}$ & Longford & Athlone & $\checkmark$ & $\checkmark$ & $\begin{array}{l}\text { Pneumonia - suppurative } \\
\text { bronchial pneumonia. }\end{array}$ \\
\hline 37 & $\begin{array}{l}\text { lung and } \\
\text { lymph node }\end{array}$ & RNALater & 1.5 & M & $\mathrm{CHX}$ & Galway & Athlone & $\checkmark$ & $\checkmark$ & Pneumonia - M. haemolytica \\
\hline 38 & $\begin{array}{l}\text { lung and } \\
\text { lymph node }\end{array}$ & RNALater & 3.5 & F & AAX & Offaly & Athlone & $\checkmark$ & $\checkmark$ & $\begin{array}{l}\text { Pneumonia - H. somni, } \\
\text { M. bovis, M. haemolytica, } \\
\text { P. multocida, T. pyogenes }\end{array}$ \\
\hline
\end{tabular}

Lesions were defined as macroscopic consolidation or abscessation of lung tissue.

$M$ male, $F$ female, $A A$ Aberdeen Angus, $A A X$ Aberdeen Angus cross, BBX Belgium Blue cross, CH Charolais, CHX Charolais cross, $F R$ Friesian, FRX Friesian cross, $L M$ Limousin, LMX Limousin cross, PTX Parthenaise cross, RBX Rotbunt cross, SIX simmental cross, WAX wagyu cross, $\checkmark=$ performed and confirmed bovine respiratory disease, $\mathrm{x}=$ not performed, $\mathrm{H}$. somni = Histophilus somni, M. bovis $=$ Mycoplasma bovis, $M$. haemolytica = Mannheimia haemolytica, . . multocida $=$ Pasteurella multocida, $\mathrm{S}$. dublin = Salmonella dublin, $T$. pyrogenes = Trueperella pyrogenes, BRSV = bovine respiratory syncytial virus, IBR $=$ infectious bovine rhinotracheitis, BPIV-3 = bovine parainfluenza 3 virus.

cut into slices less than $0.5 \mathrm{~cm}$ thick, placed in RNALater RNA Stabilization Reagent (Qiagen, Manchester, UK), stored at $4{ }^{\circ} \mathrm{C}$ overnight, and subsequently stored at $-20^{\circ}$ $\mathrm{C}$, according to the manufacturer's instructions (Table 1 ).

\section{Bacteriology, virology and histology performed at RVLs}

Aerobic bacteriology of swab samples from pneumonic lungs was performed on blood agar and McConkey agar at $37^{\circ} \mathrm{C}$ for 2 days $(n=36)$ (Additional file 1$)$, as described by Murray et al. [36]. Culture on chocolate agar under $8 \%$ $\mathrm{CO}_{2}$ for 3 days and on xylose lysine desoxycholate agar (following selenite enrichment) for 2 days at $37{ }^{\circ} \mathrm{C}$ was also conducted for the identification of Histophilus somni $(n=13)$ and Salmonella species $(n=24)$, respectively (Additional file 1) [36].

Lung and tracheal mucosa were submitted for detection of Mycoplasma bovis $(n=15)$, Histophilus somni $(n=11)$, Mannheimia haemolytica $(n=4)$ and Pasteurella multocida $(n=1)$, by real-time qPCR analyses (Additional file 1 ), which were performed as previously described [28, 37-39]. Real-time qPCR was also used to identify Bo-HV1 $(n=36)$ and reverse transcriptase qPCR was used to identify BRSV $(n=38)$, BPIV-3 $(n=35)$ and $\mathrm{BCoV}(n=34)$ (Additional file 1$)$ as previously described [12]. Positive and negative (no template) controls were included in each qPCR assay.
Sections for histology were taken from the border of grossly visible lesions on the cranial lobe $(n=21)$ (Table 1 and Additional file 1). Sections were fixed by placing them in $10 \%$ neutral-buffered formalin for 4 days, embedding them in paraffin wax, cutting them with a microtome and staining them with hematoxylin and eosin, as previously described by Murray et al. [36].

\section{Clinically healthy calves: health assessments}

To serve as a comparison, 20 lung (cranial lobe) and 20 corresponding mediastinal lymph node tissue samples were also sourced from clinically healthy $\mathrm{H}-\mathrm{F}$ calves which were slaughtered at approximately 2.5 months of age. These calves all recorded good performance prior to slaughter and achieved an average daily weight gain within a 0.25 standard deviation of their expected average daily gains.

Clinical health assessments of these calves were performed on the morning before slaughter using the Wisconsin calf health scoring criteria (https://www.vetmed.wisc.edu/dms/fapm/fapmtools/8calf/calf_respiratory_ scoring_chart.pdf) to determine a respiratory score. A calf was considered to have respiratory disease if it had a respiratory score greater than or equal to 5 as it was then showing at least two signs of respiratory disease [5]. A full 
clinical history was available for these calves including a record of veterinary treatments for BRD.

\section{Clinically healthy control calves: collection of post-mortem tissue samples}

The lungs were harvested from the calves immediately following slaughter at Teagasc Ashtown Research Centre. All surfaces and forceps were cleaned with 20\% Domestos extended germ kill bleach ( $1 \%$ final sodium hypochlorite solution) (Unilever, Surrey, UK Ltd) Virusolve $^{\circ}+$ (Amity International Healthcare; Barnsley, UK), $70 \%$ ethanol and RNaseZAP ${ }^{\mathrm{m} \omega}$ (Sigma-Aldrich ${ }^{\circ}$ Ireland Ltd., Wicklow, Ireland) initially and between samples.

The lungs were visually examined and the presence and number of lesions was recorded. Tissue samples from the cranial lobe and mediastinal lymph node were removed using sterile scalpel blades and forceps. Tissue samples were cut into slices less than $0.5 \mathrm{~cm}$ thick, placed in RNALater RNA Stabilization Reagent, stored at $4{ }^{\circ} \mathrm{C}$ overnight, and subsequently stored at $-20{ }^{\circ} \mathrm{C}$, according to the manufacturer's instructions. When lesions were present on the cranial lobe, the lesions, rather than the lesion-free regions, were sampled.

\section{DNA extraction}

DNA extraction from post-mortem tissue samples was carried out in a class II biosafety cabinet. Forceps, homogeniser and all work surfaces were cleaned initially and between samples using 20\% sodium hypochlorite solution, Virusolve,$+ 70 \%$ ethanol and RNaseZAP ${ }^{\mathrm{rx}}$. Homogeniser blades were sonicated for $10 \mathrm{~min}$ at $60{ }^{\circ} \mathrm{C}$ in molecular grade water (Sigma, Ireland), then rinsed by running while submerged in $75 \%$ ethanol and molecular grade water. DNA was extracted from post-mortem tissue samples using the Qiagen QIAamp Cador pathogen mini kit (with pre-treatments T2 (enzymatic digestion of tissue) and B1 (for difficult-to-lyse bacteria in pre-treated tissue)) (Qiagen, Manchester, UK) according to the manufacturer's instructions with some modifications to pre-treatment T2.

A small piece of each tissue sample was removed using sterile scalpel blades and forceps, placed in a sterile Petri-dish, weighed, immediately submerged in buffer ATL (Qiagen, Manchester, UK) (360 $\mu \mathrm{l}$ per $50 \mathrm{mg}$ tissue) and homogenised using a hand-held homogeniser (PRO 200, Bio-Gen Series; PRO Scientific Inc. Oxford, USA). Following homogenisation, $205 \mu \mathrm{l}$ homogenised tissue was transferred to a $1.5 \mathrm{ml}$ microcentrifuge tube (sterile) and $20 \mu \mathrm{l}$ proteinase $\mathrm{K}$ was added. The microcentrifuge tube was placed in a shaking incubator overnight $\left(300 \mathrm{rpm}, 56^{\circ} \mathrm{C}\right)$.

Pre-treatment B1 and the subsequent purification of pathogen nucleic acids from fluid samples were carried out according to the manufacturer's instructions. Following nucleic acid extraction, RNA was removed using
RNaseA solution, $4 \mathrm{mg} / \mathrm{ml}$ (Promega, Southampton, UK). This was achieved by adding $5 \mu$ l RNaseA solution to $100 \mu \mathrm{l}$ of the sample's purified nucleic acid eluate and incubating at $37{ }^{\circ} \mathrm{C}$ for $20 \mathrm{~min}$. Subsequently, the DNA was purified using a Zymo genomic DNA clean \& concentrator $^{\text {Tix }}-10$ kit (Zymo Research Corp, Irvine, CA, USA), according to the manufacturer's instructions. A Nanodrop spectrophotometer (NanoDrop Technologies, Wilmington, DE, USA) was used to quantify the DNA. All waste was autoclaved appropriately prior to disposal.

\section{S amplicon library preparation and sequencing}

One hundred and sixteen 16S rRNA gene amplicon libraries (including 6 water control libraries) were prepared by PCR amplification of an approximate $467 \mathrm{bp}$ region within the hypervariable (V3-V4) region of the $16 \mathrm{~S}$ rRNA gene in bacteria, from $50 \mathrm{ng}$ of each of the extracted and purified DNA from lung and lymph node tissue, and molecular grade water (non-template control), respectively, according to the Illumina 16S metagenomic sequencing library protocol, with modifications.

PCR was initially performed with broad spectrum $16 \mathrm{~S}$ rRNA primers (forward primer: 5' TCAGATGTGTATAAGAGACAGCCTACGGGNGGCW GCAG-3', reverse primer: 5'-GTCTCGTGGGCTCGGA GATGTGTATAAGAGACAGGACTACHVGGGTATCT AATCC-3') [34], using Kapa HiFi HotStart 2× ReadyMix DNA polymerase (Kapa Biosystems Ltd., London, UK). Cycle conditions were $95{ }^{\circ} \mathrm{C}(3 \mathrm{~min})$, then 35 cycles of $95{ }^{\circ} \mathrm{C}(30 \mathrm{~s}), 63^{\circ} \mathrm{C}(30 \mathrm{~s}), 72{ }^{\circ} \mathrm{C}(30 \mathrm{~s})$, then a final extension of $72{ }^{\circ} \mathrm{C}$ (5 min). Libraries were purified using AMPure XP beads (LABPLAN; Naas, Ireland) according to the Illumina $16 \mathrm{~S}$ metagenomic sequencing library protocol. Dual indices and Illumina sequencing adapters from the Illumina Nextera XT index kits v2 B and C (Illumina, San Diego, USA) were added to the target amplicons in a second PCR step using Kapa HotStart HiFi 2× ReadyMix DNA polymerase (Kapa Biosystems Ltd., London, UK). Cycle conditions were $95{ }^{\circ} \mathrm{C}$ (3 min), then 9 cycles of $95{ }^{\circ} \mathrm{C}(30 \mathrm{~s}), 55^{\circ} \mathrm{C}(30 \mathrm{~s}), 72{ }^{\circ} \mathrm{C}(30 \mathrm{~s})$, then a final extension of $72{ }^{\circ} \mathrm{C}(5 \mathrm{~min})$. Libraries were again purified using AMPure XP beads (LABPLAN; Naas, Ireland) according to the Illumina $16 \mathrm{~S}$ metagenomic sequencing library protocol.

Libraries were measured for purity and quantity on a Nanodrop 1000 spectrophotometer. The barcoded amplicon libraries were combined in equal concentrations into a single pool according to their Nanodrop quantification measurement. Two $\mu$ l of each negative control library was added to the pool. The library pool was then quantified using the KAPA SYBR FAST Universal qPCR kit with Illumina Primer Premix (Kapa Biosystems Ltd., London, UK) and the size was assessed with an Agilent DNA $1000 \mathrm{Kit}$ (Agilent Technologies Ireland Ltd., Dublin, Ireland) on an 
Agilent 2100 Bioanalyser (Agilent Technologies Ireland Ltd., Dublin, Ireland).

The library pool was diluted and denatured according to the Illumina MiSeq library preparation guide. The amplicon library (8 pM) was spiked with $30 \%$ denatured and diluted PhiX Illumina control library version 3 (12.5 $\mathrm{pM})$. The sequencing run was conducted on the Illumina MiSeq using the 500 cycle MiSeq reagent kit (version 2) with paired $250 \mathrm{bp}$ reads. All sequence data produced in this study has been deposited to NCBI SRA repository and are available through series accession number SRP080306.

\section{Bioinformatic analysis of amplicon library sequences}

Raw sequence reads for all samples in the study were quality controlled using the BBduk (https://sourceforge.net/projects/bbmap/) Java package. This was used to trim low quality bases ( $<20$ Phred score) from the 3 ' end of sequence read pairs and identify and remove adaptor sequences. Illumina paired reads with an insert size (length of template molecule) that was shorter than the sum of the lengths of read 1 and read 2 were merged into a single, longer read. Size selection of $467 \mathrm{bp} \pm 20 \mathrm{bp}$ sequences was performed with an in-house Perl script.

The wrapper package Quantitative Insights Into Microbial Ecology (QIIME) [40] was used to determine the operational taxonomic units (OTU)s which corresponded to the 16S rRNA gene sequences in each sample. Sequences were clustered into individual OTUs at a default similarity level of $97 \%$ using an open reference picking strategy, and subsequently, a single representative sequence from each clustered OTU was used to align to the Greengenes database. The RDP Classifier [41], using a minimum confidence cut off of 0.8, was used to determine the taxonomic classification for each OTU. Any OTUs with fewer than 50 sequences across all samples were excluded from further analysis. All OTUs with only a single read count in any sample were removed from the analysis.

\section{Statistical analysis}

Differences between relative abundances and the presence of bacterial OTUs between post-mortem lung tissue frozen at $-80{ }^{\circ} \mathrm{C}$ upon collection and post-mortem lung tissue preserved with RNA-Later, from beef calves which died from BRD, were calculated in GraphPad Prism 6 (version 6.04) using the Mann-Whitney $U$ test and the Fisher's exact test, respectively.

The Mann-Whitney U test and the Fisher's exact test in GraphPad Prism 6 (version 6.04) were used to determine if differences existed between the relative abundances and the presence, respectively, of bacterial OTUs in the lung and lymph node tissues between dairy calves which died from BRD and clinically healthy dairy calves without lung lesions present at slaughter.

Stacked bar charts displaying relative abundances of bacterial OTUs in the specific tissue types were prepared in GraphPad Prism 6 (version 6.04).

\section{Microbial DNA enrichment and metagenomics shotgun sequencing}

A lung sample from calf number 23 was chosen for shotgun sequencing as it had a high prevalence of a genus of interest (Leptotrichiacea) and did not contain many other different bacterial genera. DNA was suspended in Tris-EDTA buffer and re-quantified using the Nanodrop spectrophotometer. One $\mu \mathrm{g}$ of the DNA was enriched for microbial DNA by selective binding and removal of the CpG-methylated host DNA using the NEBNext ${ }^{\circ}$ Microbiome DNA Enrichment Kit (New England Biolabs (UK) Ltd., Hitchin, Herts, UK). The microbial-enriched DNA sample was diluted and quantified with an Agilent high sensitivity DNA kit (Agilent Technologies Ireland Ltd., Dublin, Ireland) on an Agilent 2100 Bioanalyser.

\section{Shotgun library preparation and sequencing}

One nanogram of microbial-enriched DNA was used to prepare a library using the Illumina Nextera ${ }^{\circ} \mathrm{XT}$ DNA Library Preparation Kit, according to the manufacturer's instructions. Estimation of library size was performed using an Agilent high sensitivity DNA kit on an Agilent 2100 Bioanalyser and the library was quantified using the KAPA SYBR FAST Universal qPCR kit with Illumina Primer Premix. The library was diluted and denatured according to the Illumina MiSeq library preparation guide. The $8 \mathrm{pM}$ shotgun library was spiked with $1 \%$ denatured and diluted PhiX Illumina control library version 3 (12.5 pM). A 250 bp paired end sequencing run was conducted on an Illumina MiSeq using a 500 cycle MiSeq reagent kit (version 2).

\section{Bioinformatic analysis of microbial DNA enriched shotgun sequence}

The BBduk (https://sourceforge.net/projects/bbmap/) Java package was used to trim low quality bases $(<20$ Phred score) from the 3' end of raw sequence read pairs and to identify and remove adaptor sequence. All surviving read pairs were mapped to the bovine genome (v.UMD3.1) using bwa [42] to identify host sequences. Approximately 100,000 paired-end sequences with no full-length alignment to the bovine genome were retained for de novo assembly. Contig assemblies were generated using OMEGA metagenome assembler (V1.0.2) with default settings. BLAST (BLASTN 2.3.0+) searches against the non-redundant nucleotide collection database on the NCBI website $[43,44]$ were conducted to determine 
known bacterial sequences that were most similar to the contig assemblies.

\section{Results}

Health assessments of clinically healthy calves

All of the clinically healthy H-F calves were assessed as clinically healthy on the day of slaughter and had respiratory scores based on the Wisconsin calf health scoring criteria [5] of less than 5 (Additional file 2).

\section{Lung lesions in clinically healthy calves}

Lesions (macroscopic consolidation or abscessation of lung tissue) were observed on lungs from $12 \mathrm{H}-\mathrm{F}$ calves from the 'clinically healthy' group immediately postslaughter (Additional file 3). Seven of these calves had lesions only on the cranial lobes, two had lesions on the middle lobe, two had lesions on both cranial and middle lobes and one calf had lesions on both the cranial and caudal lobes (Additional file 3). Eight calves from the 'clinically healthy' group had healthy lungs with no lesions present (Additional file 3).

In total, 5 out of the $20 \mathrm{H}-\mathrm{F}$ calves from the 'clinically healthy' group had recorded incidents of BRD (Additional file 3). These calves were all treated with Nuflor (Merck Animal Health, New Jersey) and Metacam (Boehringer Ingelheim Vetmedica GmbHm, Germany) and one calf was also treated with Dexamethasone (Norbrook, UK) and Zuprevo (Merck Animal Health, New Jersey). These antibiotic treatments were received at least 41 days before slaughter. All calves with previous recorded incidents of BRD had lung lesions present at slaughter and 7 calves with no recorded incidents of BRD also had lung lesions observed at slaughter (Additional file 3). Furthermore, one calf with lung lesions received Primidoxine (Norbrook, UK) and ASGold (Volac, UK) for treatment of enteritis 70 days before slaughter and one calf with lung lesions present received Dexamethasone and Nuflor 10 days before slaughter due to a reaction to vaccination.

\section{Negative control amplicon library PCR}

To test for contaminating 16S DNA in the PCR reagents that we used for generation of amplicon libraries, we conducted six negative (non-template) control amplicon library reactions by substituting template DNA for molecular grade water. Following PCR amplification and agarose gel electrophoresis, no amplicon bands were observed in the gel (Additional file 4 (A)) and no peaks were observed on the electropherogram images obtained from the DNA 1000 chip on an Agilent 2100 Bioanalyser (Additional file $4(\mathrm{C})$ ). In contrast, bands of the expected amplicon size (467 bp) were observed on the gel for the selected lung tissue DNA libraries and the pooled lung and lymph node tissue DNA libraries (Additional file 4
(A)). Furthermore, the electropherogram images for the selected lung tissue DNA libraries and the pooled lung and lymph node tissue DNA libraries also confirmed that these libraries contained DNA fragments corresponding to the expected amplicon size (Additional file 4 (B)).

\section{Taxonomic classification}

One hundred and fifteen bacterial OTUs were identified overall. Seventy-two were identified to genus level. Additionally, 32 OTUs could only be identified as far as family level, 7 OTUs could only be identified to order, 2 to class level and 2 only to phylum level (Additional files 5 and 6).

\section{Low numbers of classifiable reads in clinically healthy animals}

Even though equimolar amounts of each library were added to the pool that was sequenced on the MiSeq, the number of reads that were assigned to bacterial OTUs that could be classified by QIIME were much higher in lung and lymph node tissue from fatal BRD cases than from clinically healthy animals (Fig. 1). Unexpectedly, the PCR amplicon library yields were not different between BRD cases and clinically healthy animals. This indicates that in the clinically healthy animals, the $16 \mathrm{~S}$ primers were amplifying a sequence in the lung and lymph node that was not on the $16 \mathrm{~S}$ Greengenes database.

\section{OTU abundance in lung tissue}

The top 5 most abundant OTUs in the post-mortem lung samples from the beef calves which died from BRD were classified by QIIME as Pasteurellaceae ((mean relative abundance (S.E.M)) 22.4 (5.84)\%), Mycoplasma (15.1 (5.03)\%), Leptotrichiaceae (14.9 (4.40)\%), Clostridium (6.4 (4.04)\%) and Fusobacterium (5.1 (2.14)\%). The top 5 most abundant OTUs in the post-mortem lung tissue samples from dairy calves which died from BRD were classified as Leptotrichiaceae (26.0 (14.0)\%), Mycoplasma (22.0 (11.00)\%), Pasteurellaceae (16.0 (7.40)\%), Fusobacterium (15.0 (8.70)\%) and Bacteroides (8.1 (6.00)\%). The most abundant OTUs within the lung tissue samples from the clinically healthy H-F calves with lung lesions were classified as Leptotrichiaceae (20.0 (9.90)\%), Mycoplasma (15.5 (7.42)\%), Prevotella (12.3 (4.31)\%) Pasteurellaceae (10.2 (6.44)\%), and Actinobacillus (4.6 (4.59)\%). Leptotrichiaceae and Fusobacterium were undetectable in the lesion-free lung samples from the clinically healthy $\mathrm{H}-\mathrm{F}$ calves. The most abundant OTUs in lesion-free samples were Prevotella (30.7 (7.56)\%), Bacteroides (7.4 (7.38)\%), Pasteurellaceae (6.6 (5.03)\%), S24-7 (6.0 (5.24)\%), and Clostridium (5.5 (3.78)\%). 


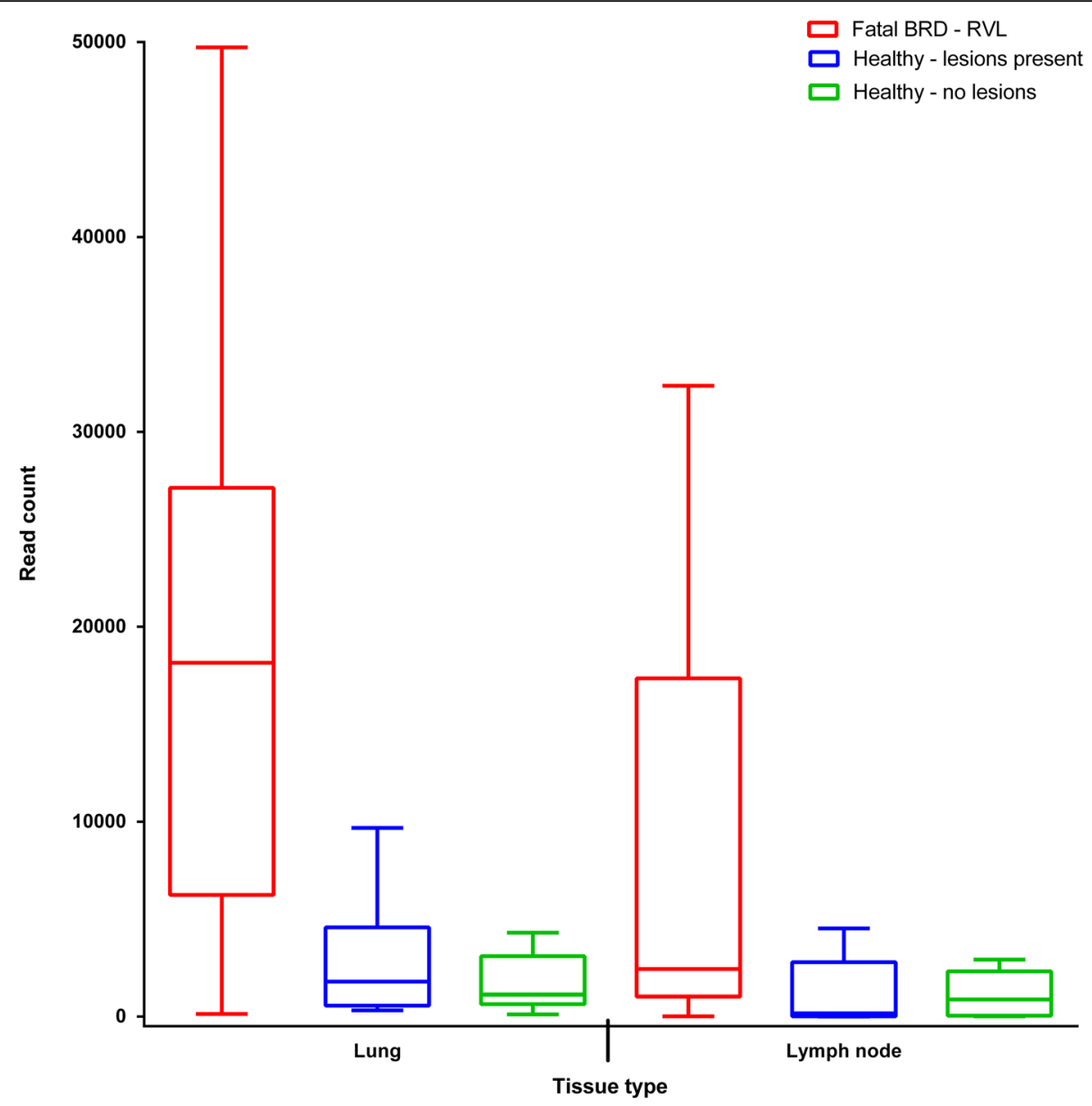

Fig. 1 Number of reads (classified as bacterial) within post-mortem lung and mediastinal lymph node tissues corresponding to each sample type; calves which died from the BRD $(n=38)$, and healthy Holstein-Friesian calves (with $(n=12)$ and without $(n=8)$ lung lesions). Fatal BRD - RVL = samples from calves with the bovine respiratory disease complex collected at regional veterinary laboratories. Healthy - lesions present = samples from healthy Holstein-Friesian calves with lung lesions. Healthy - no lesions = samples from healthy Holstein-Friesian calves without lung lesions. Boxplot = Tukey boxplot (lowest datum (whisker) is within a 1.5 interquartile range of the lower quartile, highest datum (whisker) is within a 1.5 interquartile range of the upper quartile, outliers (individual points) fall above and below these whiskers)

\section{OTU abundance in lymph node tissue}

The most abundant OTUs in lymph node tissue from beef calves which died from BRD were classified as Pasteurellaceae (18.0 (5.66)\%), Clostridium (9.6 (5.30)\%), Fusobacterium (7.3 (2.84)\%), Leptotrichiaceae (6.8 (2.66)\%) and Prevotella (6.0 (2.90)\%). Clostridium (21.9 (19.11)\%), Fusobacterium (21.7 (14.81)\%), Mycoplasma (21.3 (19.67)\%), Leptotrichiaceae (13.7 (10.68)\%) and Pasteurellaceae $(8.1$ (5.46)\%) were the most abundant OTUs in post-mortem lymph node samples from dairy calves which died from BRD. The most abundant OTUs in post-mortem lymph node samples from the clinically healthy H-F calves with lung lesions were classified as Prevotella (21.9 (10.40)\%), Lysinibacillus (16.7 (11.24)\%), Cupriavidus (8.4 (8.10)\%), Clostridium (7.5 (5.64)\%) and Leptotrichiaceae (6.8 (3.79)\%). Notably, Leptotrichiaceae and Fusobacterium OTUs were not detected in the lymph node samples from the clinically healthy $\mathrm{H}-\mathrm{F}$ calves without lung lesions. Prevotella (42.2 (11.63)\%), Enterobacteriaceae (12.5 (12.50)\%), Bacteroides (10.0 (9.96)\%), Succinivibrionaceae (7.9 (4.73)\%), and Clostridiales $(3.9(2.27) \%)$ were the most abundant OTUs that were detected in these lymph nodes.

Differences between lung and lymph node microbiomes Although OTU relative abundances in lung and lymph node were similar in some calves, the microbiomes of these two tissues were quite different in most of the animals. For example, more than half of the OTUs were identified as Clostridium in the lymph node of calf number 34 whereas no Clostridium was detected in the lung of this animal. Furthermore, Ureaplasma was the main genera detected in the lung of calf number 36 but this genera was not detected in the lymph node of this animal (Fig. 2). 


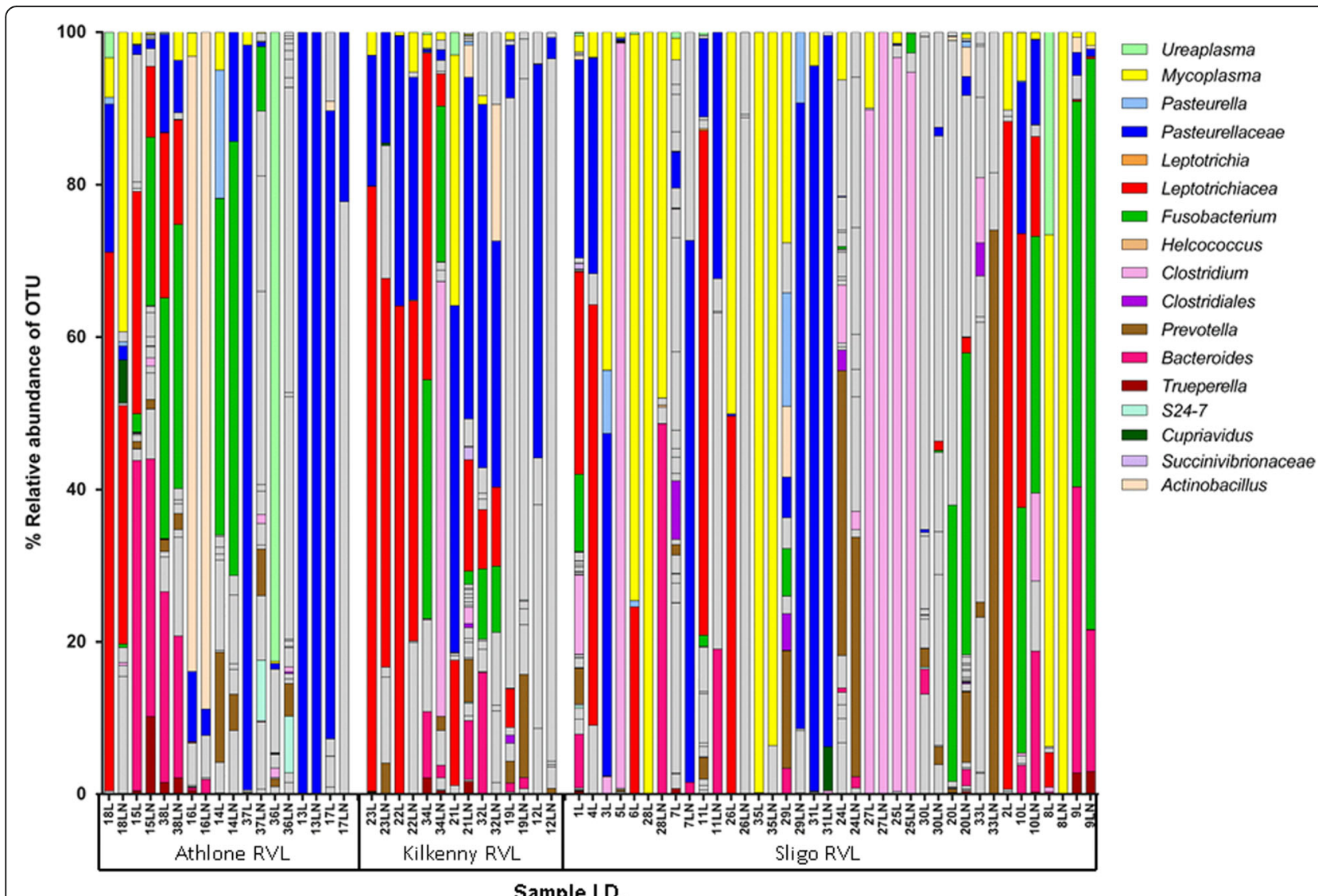

Fig. 2 Percentage relative abundance of bacteria in post-mortem lung $(L)$ and corresponding lymph node $(L N)$ samples from calves which died from bovine respiratory disease. Adjacent profiles of $L$ and $L N$ are from the same animal. Athlone = sample collected at Athlone regional veterinary laboratory (RVL). Kilkenny = sample collected at Kilkenny RVL. Sligo = sample collected at Sligo RVL. Grey bars represent infrequently occurring OTUs (see Additional file 6 for full details of all bacterial OTU classifications)

Undetected and detected genera in clinically healthy lesion-free lungs and lymph nodes

OTUs that were classified as Leptotrichiaceae, Fusobacterium, Pasteurella, Trueperella, Helcococcus, and Ureaplasma were abundant in lung and lymph node tissue samples from both beef and dairy calves that died from BRD, but these genera were not detected in either lung or lymph node tissue samples from the subset of clinically healthy $\mathrm{H}-\mathrm{F}$ calves which had no observable lung lesions $(n=8)$ (Figs. 2 and 3$)$.

At least two putative BRD-associated genera were detected in the lesion-free lungs. Mycoplasma was detected in three lung (6L, 19L and 13L) and one lymph node tissue sample (5LN) (Fig. 3). Although relative abundances of Mycoplasma were reasonably high in $6 \mathrm{~L}$ and 19L, the read counts of this genera were negligable $(6 \mathrm{~L}=308$ reads $)$ compared to the fatal BRD cases, several of which had read counts of $>10,000$ (Additional file 5). Sequences that were classified as Pasteurellaceae, a family containing species that are commonly associated with BRD were detected in three lung tissue and one lymph node tissue sample from the lesion-free calves (Fig. 3) but, again, compared to the fatal BRD cases these were negligable. The most abundant bacterial genus detected in the lesion-free samples was Prevotella which is more commonly associated with the rumen. However, the average raw read counts for Prevotella were not significantly different $(P>0.05)$ between the fatal BRD (average 212, standard deviation 446) cases and the lesion-free animals (average 498, standard deviation 610).

\section{Comparison of OTU abundance between lung samples preserved with RNALater and frozen lung samples}

There were no differences in the relative abundances or the presence of bacterial OTUs within post-mortem lung tissue samples which were frozen at $-80{ }^{\circ} \mathrm{C}$ immediately following collection and post-mortem lung tissue samples preserved with RNALater.

\section{Comparison of OTU abundance between dairy calves which died from BRD and clinically healthy calves} Bacterial OTUs associated with BRD including Fusobacterium, Mycoplasma, Trueperella and Bacteroides, and an 


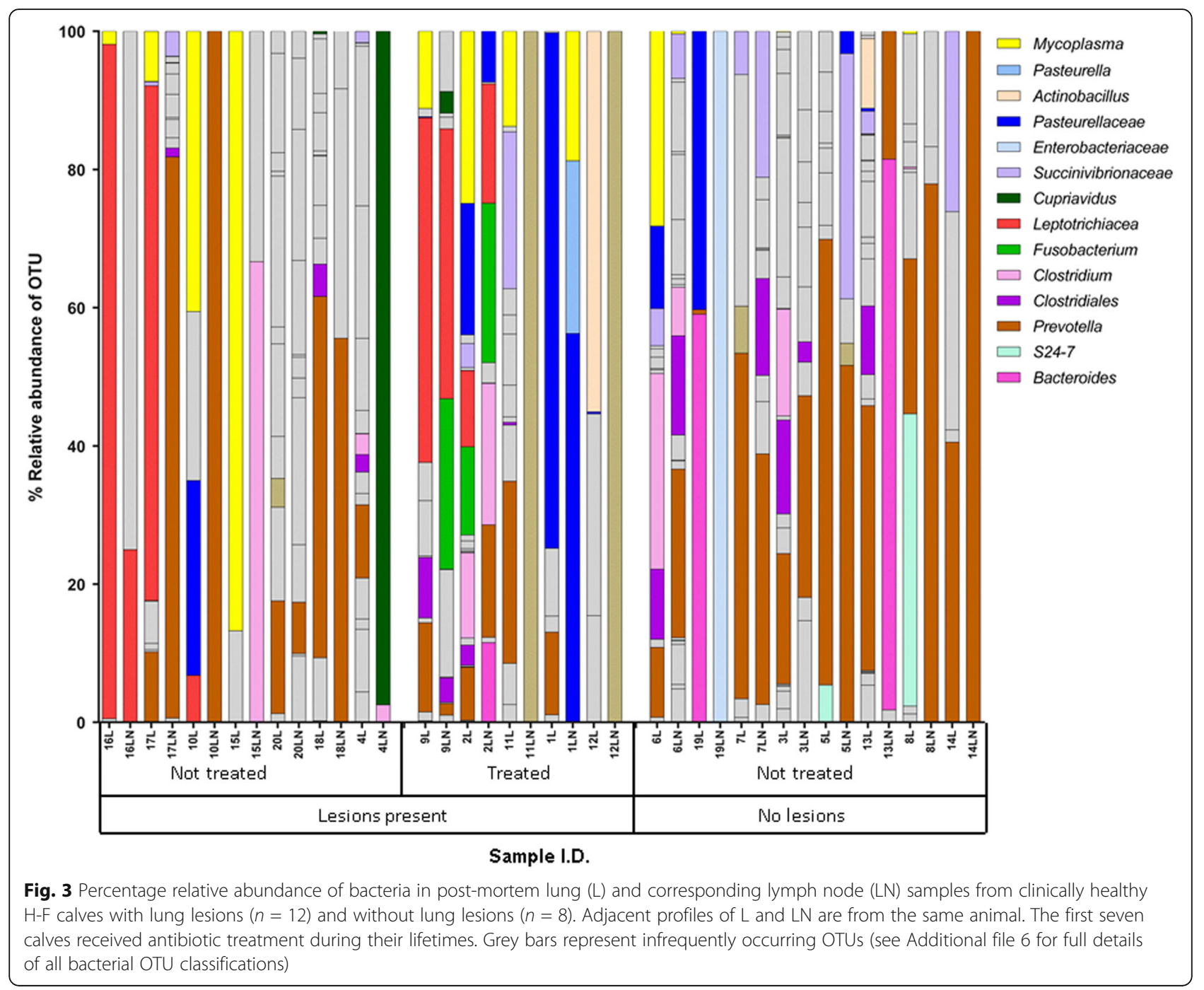

OTU not yet associated with BRD (Leptotrichiaceae), had greater relative abundances and were present more often, among the lung tissue samples collected from the dairy calves which died from BRD compared with the lung tissue samples collected from the clinically healthy H-F calves with no lung lesions $(P<0.05)$ (Additional file 7).

Leptotrichiaceae, Mycoplasma and Pasteurellaceae had greater relative abundances $(P<0.05)$ (Additional file 8 ) and were present more often $(P<0.05)$ among the lymph node tissue samples collected from the dairy calves which died from BRD compared with the lymph node tissue samples collected from the clinically healthy H-F calves with no observable lung lesions.

\section{Comparison of 16S rRNA gene amplicon sequencing and RVL qPCR}

This 16S rRNA gene amplicon sequencing assay identified many more bacteria present in post-mortem lung and lymph node tissue from calves which died from BRD than were identified from the same calves at the RVLs using both culture and uniplex PCRs on swab samples from the pneumonic lungs (Additional file 9). An OTU representing the species detected by PCR in RVLs was identified using the $16 \mathrm{~S}$ rRNA gene amplicon sequencing assay in all but one case (calf I.D. = 30) (Additional file 9). However, in seven calves (calf I.D. $=9,19,22,23,32,35,37$ ) the Mycoplasma OTU was identified using the 16S rRNA gene amplicon sequencing assay even though a PCR test at the RVLs had confirmed no Mycoplasma bovis present (Additional file 9).

The 16S rRNA gene amplicon sequencing assay identified bacterial OTUs in all ten calves (calf I.D. $=1,5,11$, $12,17,30,31,32,35,36)$ which were culture negative at the RVLs (Additional file 9). Two cases of Escherichia coli (calf I.D. $=4,27$ ), one case of Pseudomonas species (calf I.D. $=7$ ), one case of Trueperella pyogenes (calf I.D. = 18) and one case of Salmonella dublin (calf I.D. = 3) were cultured at RVLs but were not 
identified by the 16S rRNA gene amplicon sequencing assay (Additional file 9).

\section{Metagenomic shotgun sequencing of a microbial DNA enriched post-mortem lung tissue sample}

One of the post-mortem lung DNA samples (from calf number 23) was enriched for microbial DNA and completely sequenced. However, despite microbial DNA enrichment, $99 \%$ of the reads in the run mapped to the bovine genome. Approximately 100,000 sequences did not map to the bovine genome and were assembled into contigs. Most of these contigs aligned to the PhiX174 bacteriophage genome but three contigs (contig $1=2647 \mathrm{bp}$, contig $2=1376 \mathrm{bp}$, contig $3=744 \mathrm{bp}$ ) aligned to bacterial sequences. PhiX sequence was from the pre-prepared non-indexed PhiX V3 library (supplied by Illumina) which was added, as a quality control, to the microbial DNA-enriched library prior to sequencing on the MiSeq. Fluorescence from the bases in the nonindexed PhiX clusters bleeds into the fluorescence in the adjacent indexed clusters. Additional file 10 contains the sequences of the contigs which aligned to bacterial sequences. These contigs were blasted against the nonredundant nucleotide collection database on the NCBI website using the BLASTN 2.3.0+ $[45,46]$ programme in order to determine the most similar known bacterial sequences.

The top 10 blast hits for each contig are shown in Table 2. No sequences on the database were found to be $100 \%$ identical to any of the complete assembled contigs (Table 2). The top hit for contig number 1 was Sneathia amnii strain SN35 (GenBank: CP011280.1) (Table 2). It was $92 \%$ identical to $99 \%$ of contig number 1 (Table 2 ). The top hit for contig number 2 was also Sneathia amnii strain SN35 (GenBank: CP011280.1) (Table 2). It was $93 \%$ identical to $99 \%$ of contig number 2 (Table 2 ). Interestingly, contig number 2 was $100 \%$ identical to two identical partial 16S rRNA gene sequences (GenBank: KR514404.1) obtained from uncultured bacterial clones in the bovine reproductive tract of farm animals at University College Dublin (Table 2). Contig number 3 was $99 \%$ identical to $100 \%$ of Histophilus somni strain $233623 \mathrm{~S}$ ribosomal RNA gene, complete sequence (Table 2).

\section{Discussion}

At the time of writing there was a paucity of reports on high throughput $16 \mathrm{~S}$ amplicon sequencing and metagenomic shotgun sequencing in lung tissue in cattle and sheep. A detailed recent study was conducted on the lung microbiome in sheep [42] but, to our knowledge, the present report is the first high throughput $16 \mathrm{~S}$ amplicon sequencing study in lung and corresponding mediastinal lymph nodes in multiple cattle with BRD.
The cranial lung lobe tissue was chosen for investigation as it is the most common site of BRD lesions [43, 44]. Mediastinal lymph node tissue was also examined as respiratory disease causing viruses and bacteria often disseminate to these lymph nodes from the lungs [47-50]. To gain an understanding of the bacteria associated with BRD cases in Ireland, we analysed lung tissue from 'real' BRD fatalities on a number of farms in three different regions of the country. Obtaining lung and lymph node tissue from healthy 'matched' controls (i.e. same breed, sex, sire, age, farm) was not feasible in this study as it would have required slaughtering a healthy animal on the same farm as every BRD case. Instead, we had access to healthy calves which were being slaughtered as part of another study from which we took lung and lymph node tissue. In the present study, the composition of bacteria in the lungs and lymph nodes were very different between animals. In several cases, bacterial genera were different in lung and mediastinal lymph node tissues from the same calf.

In humans, the lungs of clinically healthy individuals were originally thought to be sterile [51]. However, recent studies have demonstrated that small numbers of bacteria inhabit the lungs of clinically healthy humans and sheep $[44,51]$. The current study also indicated that there are low numbers of bacteria in the lungs and additionally in the lymph nodes of clinically healthy calves. Prevotella was the most prevalent genus in terms of relative abundance in the lesion-free lungs but in terms of raw read counts, similar numbers of reads were detected in fatal BRD cases. This is a highly abundant anaerobic genus in the rumen so unlikely to actively grow in aerobic lung tissue and probably passes into the upper regions of the lung by inhalation when rumen regurgitation occurs. A possible explanation for the greater number of bacterial reads found in fatal cases of BRD compared with the clinically healthy calves (with and without lung lesions) in both tissues, is that the disease may cause a proliferation of bacteria that can overcome the natural "equilibrium" in healthy individuals.

Although the $20 \mathrm{H}-\mathrm{F}$ calves in the "clinically healthy" group displayed no clinical signs of disease at slaughter and only 5 of these calves had been previously treated for BRD, lung lesions were observed in 12 of these 20 animals $(60 \%)$. This is similar to observations by Schneider et al. [52] and Wittum et al. [53], who reported that $61 \%$ and $68 \%$, of feedlot steers with no recorded history of BRD presented with lung lesions at slaughter, respectively [53]. These authors suggested that many cases of BRD can be missed or may be sub-clinical [52].

Leptotrichiaceae, Fusobacterium, Mycoplasma, Trueperella and Bacteroides were more abundant among post-mortem lung tissue samples from dairy calves which died from BRD compared to the lesion-free lung 
Table 2 Assembled bacterial contigs description and top BLAST hits

\begin{tabular}{|c|c|c|c|}
\hline Contig number & Top 10 BLAST hits & Query cover & Percentage identity \\
\hline \multirow[t]{10}{*}{1 (2647 bp) } & 1.Sneathia amnii strain SN35, complete genome CP011280.1 & $99 \%$ & $92 \%$ \\
\hline & 2. Streptobacillus moniliformis DSM 12112, complete genome CP001779.1 & $96 \%$ & $90 \%$ \\
\hline & $\begin{array}{l}\text { 3. Streptobacillus moniliformis strain DSM } 12112 \text { 23S ribosomal RNA gene, } \\
\text { complete sequence NR_076688.1 }\end{array}$ & $96 \%$ & $90 \%$ \\
\hline & $\begin{array}{l}\text { 4. Sebaldella termitidis strain ATCC } 3338623 \text { S ribosomal RNA gene, } \\
\text { complete sequence NR_076681.1 }\end{array}$ & $96 \%$ & $89 \%$ \\
\hline & 5. Sebaldella termitidis ATCC 33386, complete genome CP001739.1 & $96 \%$ & $89 \%$ \\
\hline & $\begin{array}{l}\text { 6. Leptotrichia buccalis strain C-1013-b } 23 \text { S ribosomal RNA gene, complete } \\
\text { sequence NR_076664.1 }\end{array}$ & $96 \%$ & $88 \%$ \\
\hline & 7. Leptotrichia buccalis DSM 1135, complete genome CP001685.1 & $96 \%$ & $88 \%$ \\
\hline & $\begin{array}{l}\text { 8. Leptotrichia sp. oral taxon } 212 \text { strain W10393, complete genome } \\
\text { CP012410.1 }\end{array}$ & $96 \%$ & $87 \%$ \\
\hline & 9. Fusobacterium hwasookii ChDC F206, complete genome CP013336.1 & $96 \%$ & $83 \%$ \\
\hline & 10. Propionigenium maris $23 \mathrm{~S}$ rRNA gene, strain DSM 9537 T AJ307979.1 & $93 \%$ & $83 \%$ \\
\hline \multirow[t]{10}{*}{$2(1376$ bp) } & 1. Sneathia amnii strain SN35, complete genome CP011280.1 & $99 \%$ & $93 \%$ \\
\hline & $\begin{array}{l}\text { 2. Uncultured bacterium clone T21VE9_4 } 165 \text { ribosomal RNA gene, } \\
\text { partial sequence KR514404.1 }\end{array}$ & $67 \%$ & $100 \%$ \\
\hline & $\begin{array}{l}\text { 3. Uncultured bacterium clone T21UE13_2 } 165 \text { ribosomal RNA gene, } \\
\text { partial sequence KR514401.1 }\end{array}$ & $67 \%$ & $100 \%$ \\
\hline & $\begin{array}{l}\text { 4. Uncultured bacterium clone T21VE9_24 } 16 \text { S ribosomal RNA gene, } \\
\text { partial sequence KR514494.1 }\end{array}$ & $67 \%$ & $99 \%$ \\
\hline & $\begin{array}{l}\text { 5. Uncultured bacterium clone T21VE9_36 } 16 \text { S ribosomal RNA gene, } \\
\text { partial sequence KR514405.1 }\end{array}$ & $67 \%$ & $99 \%$ \\
\hline & $\begin{array}{l}\text { 6. Uncultured bacterium clone T21UE13_23 16S ribosomal RNA gene, } \\
\text { partial sequence KR514403.1 }\end{array}$ & $67 \%$ & $99 \%$ \\
\hline & $\begin{array}{l}\text { 7. Uncultured bacterium clone T21UE13_12 16S ribosomal RNA gene, } \\
\text { partial sequence KR514402.1 }\end{array}$ & $67 \%$ & $99 \%$ \\
\hline & $\begin{array}{l}\text { 8. Uncultured bacterium clone H94 } 165 \text { ribosomal RNA gene, partial } \\
\text { sequence KC } 894542.1\end{array}$ & $69 \%$ & $99 \%$ \\
\hline & $\begin{array}{l}\text { 9. Uncultured bacterium clone H35 } 16 \mathrm{~S} \text { ribosomal RNA gene, partial } \\
\text { sequence KC } 894531.1\end{array}$ & $69 \%$ & $99 \%$ \\
\hline & $\begin{array}{l}\text { 10. Uncultured bacterium clone T21UE060212_22 16S ribosomal RNA } \\
\text { gene, partial sequence KR514400.1 }\end{array}$ & $67 \%$ & $99 \%$ \\
\hline \multirow[t]{10}{*}{3 (744 bp) } & $\begin{array}{l}\text { 1. Histophilus somni strain } 2336235 \text { ribosomal RNA gene, complete } \\
\text { sequence NR_103965.1 }\end{array}$ & $100 \%$ & $99 \%$ \\
\hline & $\begin{array}{l}\text { 2. Histophilus somni strain 129P 23S ribosomal RNA gene, complete } \\
\text { sequence NR_076444.1 }\end{array}$ & $100 \%$ & $99 \%$ \\
\hline & 3. Haemophilus somnus 2336, complete genome CP000947.1 & $100 \%$ & $99 \%$ \\
\hline & 4. Haemophilus somnus 129PT, complete genome CP000436.1 & $100 \%$ & $99 \%$ \\
\hline & $\begin{array}{l}\text { 5. Pasteurella multocida subsp. multocida } \mathrm{OH} 4807 \text {, complete genome } \\
\text { CP004391.1 }\end{array}$ & $100 \%$ & $94 \%$ \\
\hline & $\begin{array}{l}\text { 6. Pasteurella multocida subsp. multocida str. HN06, complete genome } \\
\text { CP003313.1 }\end{array}$ & $100 \%$ & $94 \%$ \\
\hline & $\begin{array}{l}\text { 7. Pasteurella multocida subsp. multocida PMTB2.1, complete genome } \\
\text { CP007205.1 }\end{array}$ & $100 \%$ & $94 \%$ \\
\hline & $\begin{array}{l}\text { 8. Pasteurella multocida subsp. multocida strain Pm70 } 23 \text { S ribosomal RNA } \\
\text { gene, complete sequence NR_103956.1 }\end{array}$ & $100 \%$ & $94 \%$ \\
\hline & $\begin{array}{l}\text { 9. Pasteurella multocida subsp. multocida str. Pm70, complete genome } \\
\text { AE004439.1 }\end{array}$ & $100 \%$ & $94 \%$ \\
\hline & 10. Pasteurella multocida strain Pm-3, complete genome CP014618.1 & $100 \%$ & $94 \%$ \\
\hline
\end{tabular}


tissue samples from clinically healthy H-F calves. Additionally, Leptotrichiaceae, Mycoplasma and Pasteurellaceae had significantly greater relative abundances among post-mortem lymph node tissue samples from dairy calves which died from BRD relative to the clinically healthy, lung lesion-free H-F calves. It is also possible that other bacterial OTUs were more abundant and present more often within tissue samples from BRD-affected relative to clinically healthy dairy calves, however, as this study lacked power due to restricted sample sizes of BRDaffected dairy calves and lung lesion-free, clinically healthy dairy calves, these differences were not statistically different.

It is possible that the bacterial OTUs present among the samples obtained from the RVLs were the result of contaminating bacteria which propagated post-mortem. However, this is unlikely as most bacterial OTUs found among these samples were also found in the samples from the clinically healthy calves with lung lesions, in which the samples were obtained immediately following slaughter.

\section{Leptotrichiaceae}

The Leptotrichiaceae OTU was more abundant within post-mortem lung and lymph node tissue samples from dairy calves which died from BRD relative to post-mortem lung and lymph node tissue samples from clinically healthy, lung lesion-free, H-F calves. Additionally, it was one of the most abundant OTUs identified within tissue samples from beef and dairy calves which died from BRD and was absent in samples from clinically healthy H-F calves which had no lung lesions.

The prevalence of OTUs that were classified as the bacterial family Leptotrichiaceae in lung and lymph node tissue from fatal BRD cases and lung lesions from clinically healthy cattle was of particular interest as members of this family were recently proposed to be associated with lung disease in humans. Leptotrichiaceae species are not currently associated with BRD and have not been previously described in lungs or mediastinal lymph nodes of cattle. All members of this bacterial family are facultative to obligate anaerobic Gram-negative rods [54]. They can occur in anoxic environments as well as oral and intestinal environments [54]. Although little is known about their role in disease, mainly due to the difficulties associated with their isolation and identification, they have been suggested as emerging pathogens [55]. A member of this family within the genus Leptotrichia was identified in bronchoalveolar lavage fluid from an elderly man with pneumonia and was hypothesized to be responsible for the disease [56]. Additionally, a member of the genus Sneathia was hypothesised to be responsible for late-onset bronchiolitis obliterans syndrome in a lung transplant recipient [57]. Furthermore, species within the
Leptotrichia genus have been isolated from blood cultures of patients with lesions in the oral mucosa [55] and from blood cultures from patients with anaerobic bloodstream infection receiving high-dose chemotherapy [58].

As the OTU sequence for Leptotrichiaceae found in the present study was not identical to any known genus we wanted to achieve better classification with longer DNA sequences than was possible with the 472 bp V3-V4 16S sequence. To do this we partially sequenced the genome of this unknown species of bacteria by metagenomic shotgun sequencing and de novo assembly of a bacterial DNA enriched postmortem lung tissue sample. From this we obtained three bacterial sequence contigs which were $2647 \mathrm{bp}$, $1376 \mathrm{bp}$ and $744 \mathrm{bp}$ long. The $744 \mathrm{bp}$ contig corresponded to a known BRD-associated bacterial species, Histophilus somni. A BLAST search against the NCBI cultured bacteria database showed the 2647 bp and 1376 bp contigs were most similar (92 and 93\% identity respectively) to Sneathia amnii. A BLAST search against the $\mathrm{nr} / \mathrm{nt}$ collection showed that part of one of the Leptotrichiaceae contigs (67\%) was $100 \%$ identical to an uncultured clone. As this uncultured clone (GenBank: KR514404.1, submitted by $\mathrm{Lu}, \mathrm{J}$ ) was obtained from the bovine reproductive tract of farm animals at University College Dublin, it appears to be a novel species that is present in at least two microbiomes in cattle. From the present study it is not possible to infer whether this novel Leptotrichiaceae species is pathogenic and causing lung lesions in cattle or wheteher it is merely able to grow opportunistically in the relatively anaerobic lung lesions (some Leptotrichiaceae are facultative anaerobes) which have been caused by known pathogens. In lung tissue samples from the calves in this study, the Leptotrichiaceae OTU always co-occurred with either Pasteurellaceae, Mycoplasma or Fusobacterium OTUs.

\section{Pasteurellaceae}

Pasteurellaceae was one of the most abundant OTUs identified overall and was consistently more abundant in post-mortem lymph node samples from dairy calves which died from BRD compared with those from clinically healthy, lung lesion-free, H-F calves. Many bacterial species implicated in BRD, including Mannheimia haemolytica, Histophilus somni, Bibersteinia trehalosi and Pasteurella multocida, belong to the Pasteurellaceae family. Indeed, these bacterial species possess many virulence factors which enable them to become pathogenic $[17-19,38,59,60]$. Furthermore they have been commonly isolated from the lungs and respiratory tracts of cattle with BRD and healthy cattle $[11,17,19,22,61-64]$. 


\section{Fusobacterium}

Fusobacterium was one of the most abundant OTUs identified. Furthermore, within the post mortem lung tissue samples, it was found to be more abundant among samples from dairy calves which died from BRD relative to the samples from the clinically healthy, lung lesionfree, H-F calves. Additionally, it was not present within any of the tissue samples from the calves that had no lung lesions. This was not surprising as Fusobacterium species are commonly isolated from chronic, abscessing lung lesions in cattle with BRD [11]. Furthermore, this genus contains the anaerobic species Fusobacterium necrophorum, which is a significant opportunistic animal pathogen with several virulence factors [65] and it has been previously isolated from ruminant respiratory tracts $[63,66]$ and pneumonic bovine lungs [67].

\section{Mycoplasma}

Mycoplasma was one of the most abundant OTUs present in the post-mortem lung and lymph node samples. It was found to be more abundant among the tissue samples from dairy calves which died from BRD relative to the tissue samples from the clinically healthy, lung lesion-free, H-F calves. This is consistent with previous studies which reported Mycoplasma to be one of the dominant genera in nasopharyngeal swab samples from cattle at feedlot [26, 33], despite being infrequent in cattle at feedlot entry [26]. Additionally, this result is concordant with previous observations which report that Mycoplasma species bovis, dispar and bovirhinis, were identified more often in pneumonic lungs and respiratory tracts compared with clinically healthy lungs and respiratory tracts [25, 62, 68, 69].

Although Mycoplasma bovis is a recognised BRD pathogen [70] and is commonly screened for in veterinary diagnostic laboratories [71, 72], the other major Mycoplasma species are not generally screened. However, they may be responsible for BRD as Mycoplasma dispar is a recognised pathogenic Mycoplasma species [10], capable of colonising the lower respiratory tract and caused pneumonia when inoculated into gnotobiotic calves [73]. Moreover, it has been cultured from the respiratory tracts of calves presenting with BRD $[63,74]$ and has been isolated from lavage fluids of calves with recurrent respiratory disease [68]. Furthermore, although Mycoplasma arginine and Mycoplasma bovirhinis did not cause pneumonia following inoculation into gnotobiotic calves, these species have also been isolated from lavage fluids of calves with recurrent respiratory disease [68] and pneumonic lungs [68, 69] and have been suggested to act as co-pathogens which may intensify respiratory disease symptoms [69, 74].

\section{Ureaplasma}

Ureaplasmas, also belong to the same family as the Mycoplasmas, and are pathogenic bacteria which were initially associated with urogenital tract infections but have also been isolated from pneumonic bovine lungs $[10,68,75]$. The species Ureaplasma diversum has been associated with clinical respiratory disease [75, 76]. As Ureaplasma was found to be present in pneumonic lung tissue samples from calves which died from BRD, this genus may be an important contributor to BRD which is often overlooked.

\section{Bacterioides}

Bacterioides species are associated with bacterial pneumonia $[1,18]$. They had high relative abundances within the post-mortem lung and lymph node tissue samples taken from beef and dairy calves which died from BRD. Furthermore, they were more abundant among samples from dairy calves which died from BRD compared with clinically healthy lesion-free dairy calves. This result was expected as Bacterioides species have been commonly isolated from chronic, abscessing lung lesions in cattle with BRD [11] and have previously been cultured from pneumonic bovine lungs [67].

\section{NGS $16 \mathrm{~S}$ compared to RVL results}

The bacterial 16S rRNA gene amplicon sequencing assay identified many more bacteria from calves which died from BRD than the culture and PCR tests carried out at the RVLs. However, at the RVLs, there were several cases where bacterial species were identified by culture, and one case where a bacterial species was identified by PCR, which were not identified by the bacterial $16 \mathrm{~S}$ rRNA gene amplicon sequencing assay. This may be because only a small part of the cranial lobe region of the lung and the mediastinal lymph node were examined with the $16 \mathrm{~S}$ sequencing assay, whereas culture was performed on swab samples covering the whole lung area at RVLs. In the present study, the $16 \mathrm{~S}$ rRNA gene amplicon assay showed that many bacteria which are not currently screened for by PCR or cultured at RVLs were found to be present within the cranial lung lobes and mediastinal lymph nodes from calves which died from BRD, including Leptotrichiaceae, Fusobacterium, Helcococcus, Mycoplasma, Ureaplasma, and Bacteroides.

Although Mycoplasma bovis is currently screened for by PCR in RVLs, the bacterial 16S rRNA gene amplicon sequencing assay found the Mycoplasma OTU to be present in seven calves which tested negative for Mycoplasma bovis by PCR at RVLs. This is most likely because other species belonging to the Mycoplasma genus, other than Mycoplasma bovis, were present within these samples. Despite Helcococcus species not being currently associated with BRD, Helcococcus ovis 
has been isolated from sheep with respiratory disease [77], a calf with valvular endocarditis [78] and from a horse with a pulmonary abscess [79]. Therefore, implementation of this $16 \mathrm{~S}$ rRNA amplicon sequencing assay at veterinary diagnostic laboratories would enable discovery of more of the bacteria responsible for each case of BRD as the present study has highlighted that this assay can identify more known bacteria (both culturable and nonculturable) than culture, and can also identify yet unknown and unculturable bacteria in tissue samples, which cannot be identified by culture and PCR tests currently carried out at veterinary diagnostic laboratories.

Next generation sequencing can revolutionise BRD bacterial diagnostics. By using a single $16 \mathrm{~S}$ rRNA amplicon sequencing assay, the bacteria present in a tissue sample can be accurately identified. A limitation of the Illumina MiSeq based bacterial $16 \mathrm{~S}$ rRNA gene amplicon sequencing assay is that currently, it is unable to identify bacterial OTUs to species level due to the fact that the maximum read length is $<550$ base pairs. However, the entire $16 \mathrm{~S}$ rRNA gene can be sequenced with Pacific Biosciences' single molecule, real-time sequencing technology but this is expensive and the error rate for individual reads are high [80].

\section{Conclusions}

In conclusion, we have shown that a convenient, single universal bacterial 16S rRNA gene amplicon sequencing assay can detect the bacterial OTUs present in a BRDaffected lung or lymph node sample. Using this assay, we have characterised the microbiomes of the cranial lung lobe and mediastinal lymph node from calves which died from BRD and from clinically healthy H-F calves. We have confirmed that the cranial region of bovine lungs are not sterile environments and that some bacteria associated with BRD can be present within the lung and lymph node tissues of clinically healthy calves as well as those calves which were suffering from BRD. However, the frequency of the detection of bacteria associated with BRD is lower in the lungs and lymph nodes of clinically healthy calves compared with calves which died from BRD.

Furthermore, we have identified bacterial sequences corresponding to an unidentified species, which is classified as a member of the bacterial family Leptotrichiaceae, that was a dominant species in bovine lung lesions in BRD cases and absent in healthy lesion-free lung tissue. Therefore, this 16S rRNA gene amplicon sequencing assay has potential to expedite BRD diagnosis and identify as of yet unknown bacteria which may be key players in BRD development and progression. Furthermore, results from the 16S rRNA gene amplicon sequencing assay, presented in this paper, highlight that continually focusing on bacterial agents that have been commonly associated with BRD could lead to common commensals that may offer a pathogenic threat being neglected. This could result in increased morbidity, increased mortality, and decreased performance in beef and dairy calves.

The present study shows that further NGS study of large numbers of healthy and BRD lung and lymph node tissue samples to generate a comprehensive view of the microbiome of healthy and diseased bovine lungs is warranted.

\section{Additional files}

Additional file 1: Description of post-mortem tissue samples collected, sample preservation methods and the diagnostics tests performed on these samples at regional veterinary laboratories (RVL)s. (XLSX 18 kb)

Additional file 2: Clinical assessment report from the clinically healthy calves on the morning before slaughter. (DOCX $31 \mathrm{~kb}$ )

Additional file 3: Description of the lungs from the clinically healthy calves observed following slaughter. (DOCX $14 \mathrm{~kb}$ )

Additional file 4: Agilent 2100 bioanalyzer DNA Electrophoresis assay results (DOCX $222 \mathrm{~kb}$ )

Additional file 5: Operational taxonomic unit absolute read counts table. (XLSX $5305 \mathrm{~kb}$ )

Additional file 6: Operational taxonomic unit relative abundance table. (XLSX $78 \mathrm{~kb}$ )

Additional file 7: Comparison of OTU abundance between postmortem lung tissue samples from dairy calves which died from BRD $(n=6)$ and clinically healthy calves without lung lesions $(n=8)$. (DOCX $35 \mathrm{~kb})$

Additional file 8: Comparison of OTU abundance between postmortem lymph node tissue samples from dairy calves which died from $\operatorname{BRD}(n=5)$ and clinically healthy calves without lung lesions $(n=8)$. (DOCX $33 \mathrm{~kb}$ )

Additional file 9: Description of the results of the PCR and culture tests carried out at the regional veterinary laboratories and the corresponding results of the OTUs identified by $16 \mathrm{~S}$ rRNA amplicon sequencing. (DOCX $24 \mathrm{~kb})$

Additional file 10: Assembled bacterial contig sequences. (DOCX $30 \mathrm{~kb}$ )

\section{Abbreviations}

BCoV: Bovine coronavirus; Bo-HV1: Bovine herpesvirus 1; BPIV-3: Bovine parainfluenza 3 virus; BRD: Bovine respiratory disease; BRSV: Bovine respiratory syncytial virus; BVDV: Bovine viral diarrhoea virus; H-F: Holstein-Friesian; NGS $16 S$ amplicon analysis: Next generation sequencing of 165 ribosomal RNA gene PCR amplicons; OTU: Operational taxonomic unit; QIIME: Quantitative insights into microbial ecology; rRNA: Ribosomal RNA; RVL: Regional veterinary laboratory

\section{Acknowledgements}

The authors would like to acknowledge the veterinary pathlogogists and technicians at the regional veterinary laboratories for sample acquisition and collection.

\section{Funding}

This research, including all experimental procedures, was funded by the Irish Government under the National Development Plan 2007-2013, Department of Agriculture, Food and the Marine (DAFM) Research Stimulus Fund 11/S/ 131 (B. Earley, Principal Investigator) and EU project: 311,825 (B. Earley, Principal Investigator). The healthy calves were part of a study funded by DAFM Research Stimulus Fund 11/S/322 (D.A. Kenny, Principal Investigator). The funding bodies were not involved in the design of the study and collection, analysis, and interpretation of data or in writing of the manuscript.

\section{Availability of data and materials}

All sequence data produced in this study has been deposited to NCBI SRA repository and are available through series accession number SRP080306. 


\section{Authors' contributions}

BE, MSM, DAK, MM, SW, AKK, PC and DJ designed the study. GM obtained the samples from fatal BRD cases at the regional veterinary laboratories (RVL) and performed culture and PCR at the RVL. DJ and MSM performed the NGS experiments. PC performed the bioinformatics analysis. DJ and MSM wrote the manuscript. All authors contributed to data interpretation and approved the final version of the manuscript.

\section{Competing interests}

The authors declare that they have no competing interests.

\section{Consent for publication}

Not applicable.

\section{Ethics approval and consent to participate}

Tissue samples from healthy calves were harvested from a cohort of slaughtered calves in an EU licenced abattoir as part of a separate study examining the effect of early life nutrition on adipogenesis in calves. This latter study was licenced (project authorisation number: AE19132/P014) by the Irish Health Products Regulatory Authority in accordance with the European Union (Protection of Animals used for Scientific Purposes) Regulations 2012 (SI 543/2012), the European Union (Protection of Animals used for Scientific Purposes) (Amendment) Regulations 2013 (SI 434/2013) and the European Union (Protection of Animals used for Scientific Purposes) (Amendment) Regulations 2014 (SI 174/2014). As the tissue samples used in the current study were obtained post-mortem, this study, therefore, did not require a separate licence.

Tissue samples from calves which died from BRD were sourced from calves which succumbed to disease on-farm and were submitted for post-mortem examination. No permissions or licences were required to sample these animals as they were being sampled as part of a diagnostic process by the Department of Agriculture to achieve a diagnosis for the herd. None of the sick animals were euthanised for the purposes of this study.

\section{Publisher's Note}

Springer Nature remains neutral with regard to jurisdictional claims in published maps and institutional affiliations.

\begin{abstract}
Author details
${ }^{1}$ Animal and Bioscience Research Department, Animal \& Grassland Research and Innovation Centre, Teagasc Grange, Dunsany, Co. Meath, Ireland. ${ }^{2}$ School of Agriculture Food Science and Veterinary Medicine, University College Dublin, DublinBelfield, Dublin 4, Ireland. ${ }^{3}$ Department of Agriculture, Food and the Marine, Regional Veterinary Laboratory, Sligo, Co. Sligo, Ireland. ${ }^{4}$ Livestock Systems Research Department, Animal \& Grassland Research and Innovation Centre, Teagasc Grange, Dunsany, Co. Meath, Ireland.
\end{abstract}

\section{Received: 26 November 2016 Accepted: 21 April 2017} Published online: 02 May 2017

\section{References}

1. Griffin D, Chengappa MM, Kuszak J, McVey DS. Bacterial pathogens of the bovine respiratory disease complex. Vet Clin N Am Food Anim Pract. 2010;26:381-94.

2. Taylor JD, Fulton RW, Lehenbauer TW, Step DL, Confer AW. The epidemiology of bovine respiratory disease: What is the evidence for preventive measures? Can. Vet. J. 2010;51:1351-9.

3. Brooks KR, Raper KC, Ward CE, Holland BP, Krehbiel CR, Step DL. Economic effects of bovine respiratory disease on feedlot cattle during backgrounding and finishing phases. Prof. Anim. Sci. 2011;27:195-203.

4. Arcangioli M-A, Duet A, Meyer G, Dernburg A, Bézille P, Poumarat F, Le Grand D. The role of Mycoplasma bovis in bovine respiratory disease outbreaks in veal calf feedlots. Vet J. 2008;177:89-93.

5. McGuirk SM, Peek SF. Timely diagnosis of dairy calf respiratory disease using a standardized scoring system. Anim Health Res Rev. 2014;15:145-7.

6. DAFM/AFBI. All-Ireland animal disease surveillance report 2014. https://www. agriculture.gov.ie/media/migration/animalhealthwelfare/labservice/rvlreports/ 2014_All_Island_Disease_Surveillance_Report.pdf.

7. Edwards TA. Control methods for bovine respiratory disease for feedlot cattle. Vet Clin N Am Food Anim Pract. 2010;26:273-84.
8. Hay KE, Barnes TS, Morton JM, Clements ACA, Mahony TJ. Risk factors for bovine respiratory disease in Australian feedlot cattle: Use of a causal diagram-informed approach to estimate effects of animal mixing and movements before feedlot entry. Prev. Vet. Med. 2014;117:160-9.

9. Neibergs HL, Seabury CM, Wojtowicz AJ, Wang Z, Scraggs E, Kiser JN, Neupane M, Womack JE, Van Eenennaam A, Hagevoort GR, et al. Susceptibility loci revealed for bovine respiratory disease complex in pre-weaned holstein calves. BMC Genomics. 2014;15:1164.

10. Howard CJ. Mycoplasmas and bovine respiratory disease: studies related to pathogenicity and the immune response-a selective review. Yale J. Biol. Med. 1983;56:789-97.

11. Callan R, Garry F. Biosecurity and bovine respiratory disease. Veterinary Clinics: Food Animal Practice. 2002;18:57-77.

12. O'Neill R, Mooney J, Connaghan E, Furphy C, Graham DA. Patterns of detection of respiratory viruses in nasal swabs from calves in Ireland: a retrospective study. Vet Rec. 2014;175:351.

13. Ng TFF, Kondov NO, Deng X, Van Eenennaam A, Neibergs HL, Delwart E. A metagenomics and case-control study to identify viruses associated with bovine respiratory disease. J Virol. 2015;89:5340-9.

14. Mitra N, Cernicchiaro N, Torres S, Li F, Hause BM. Metagenomic characterization of the virome associated with bovine respiratory disease in feedlot cattle identified novel viruses and suggests an etiologic role for influenza D virus. J Gen Virol. 2016;97:1771-84.

15. Caswell JL. Failure of respiratory defenses in the pathogenesis of bacterial pneumonia of cattle. Vet Pathol. 2014;51:393-409.

16. Gershwin $\sqcup$, Van Eenennaam AL, Anderson ML, McEligot HA, Shao MX, Toaff-Rosenstein R, Taylor JF, Neibergs HL, Womack J. Single pathogen challenge with agents of the bovine respiratory disease complex. PLoS One. 2015;10:e0142479.

17. Dabo SM, Taylor JD, Confer AW. Pasteurella multocida and bovine respiratory disease. Anim Health Res Rev. 2007;8:129-50.

18. Panciera RJ, Confer AW. Pathogenesis and pathology of bovine pneumonia. Vet Clin N Am Food Anim Pract. 2010;26:191-214.

19. Griffin D. Bovine pasteurellosis and other bacterial infections of the respiratory tract. Vet Clin N Am Food Anim Pract. 2010;26:57-71.

20. McVey DS. BRD research needs in the next 10-20 years. Anim Health Res Rev. 2009;10:165-7.

21. Larson RL, Step DL. Evidence-based effectiveness of vaccination against Mannheimia haemolytica, Pasteurella multocida, and Histophilus somni in feedlot cattle for mitigating the incidence and effect of bovine respiratory disease complex. Vet Clin N Am Food Anim Pract. 2012;28:97-106.e107.

22. Gagea MI, Bateman KG, van Dreumel T, McEwen BJ, Carman S, Archambault M, Shanahan RA, Caswell JL. Diseases and pathogens associated with mortality in Ontario beef feedlots. J Vet Diagn Investig. 2006;18:18-28.

23. Fulton RW, Confer AW. Laboratory test descriptions for bovine respiratory disease diagnosis and their strengths and weaknesses: Gold standards for diagnosis, do they exist? Can. Vet. J. 2012;53:754-61.

24. Padmanabhan R, Mishra AK, Raoult D, Fournier P-E. Genomics and metagenomics in medical microbiology. J Microbiol Methods. 2013;95:415-24.

25. Marques LM, Buzinhani M, Yamaguti M, Oliveira RC, Ferreira JB, Mettifogo E, Timenetsky J. Use of a polymerase chain reaction for detection of Mycoplasma Dispar in the nasal mucus of calves. J Vet Diagn Investig. 2007;19:103-6.

26. Holman DB, Timsit E, Alexander TW. The nasopharyngeal microbiota of feedlot cattle. Sci. Rep. 2015;5:15557.

27. Tegtmeier $C$, Angen $\varnothing$, Ahrens $P$. Comparison of bacterial cultivation, PCR, in situ hybridization and immunohistochemistry as tools for diagnosis of Haemophilus somnus pneumonia in cattle. Vet Microbiol. 2000;76:385-94.

28. Bell CJ, Blackburn P, Elliott M, Patterson TIAP, Ellison S, Lahuerta-Marin A, Ball HJ. Investigation of polymerase chain reaction assays to improve detection of bacterial involvement in bovine respiratory disease. J Vet Diagn Investig. 2014;26:631-4.

29. Woo PCY, Lau SKP, Teng JLL, Tse H, Yuen KY. Then and now: use of 165 rDNA gene sequencing for bacterial identification and discovery of novel bacteria in clinical microbiology laboratories. Clin Microbiol Infect. 2008;14:908-34.

30. Taylor JD, Doyle DJ, Blackall PJ, Confer AW. Use of REP-PCR and 16S rRNA gene sequencing for comparison of Mannheimia haemolytica isolates obtained from fatal cases of bovine respiratory disease in the USA and Australia. Aust Vet J. 2014;92:15-23.

31. McCabe MS, Cormican P, Keogh K, O'Connor A, O'Hara E, Palladino RA, Kenny DA, Waters SM. Illumina miSeq phylogenetic amplicon sequencing shows a large reduction of an uncharacterised Succinivibrionaceae and an 
increase of the Methanobrevibacter gottschalkii clade in feed restricted cattle. PLoS One. 2015;10:e0133234.

32. Allen EK, Koeppel AF, Hendley JO, Turner SD, Winther B, Sale MM. Characterization of the nasopharyngeal microbiota in health and during rhinovirus challenge. Microbiome. 2014;2:22.

33. Timsit E, Workentine M, Schryvers AB, Holman DB, van der Meer F, Alexander TW. Evolution of the nasopharyngeal microbiota of beef cattle from weaning to 40 days after arrival at a feedlot. Vet Microbiol. 2016;187:75-81.

34. Klindworth A, Pruesse E, Schweer T, Peplies J, Quast C, Horn M, Glöckner FO. Evaluation of general 165 ribosomal RNA gene PCR primers for classical and next-generation sequencing-based diversity studies. Nucleic Acids Res. 2013;41:e1.

35. Sontakke S, Cadenas MB, Maggi RG, Diniz PPVP, Breitschwerdt EB. Use of broad range16S rDNA PCR in clinical microbiology. J Microbiol Methods. 2009;76:217-25.

36. Murray GM, More SJ, Sammin D, Casey MJ, McElroy MC, O'Neill RG, Byrne WJ, Earley B, Clegg TA, Ball H, et al. Pathogens, patterns of pneumonia, and epidemiologic risk factors associated with respiratory disease in recently weaned cattle in Ireland. J Vet Diagn Investig. 2017;29:20-34.

37. Sachse K, Salam HSH, Diller R, Schubert E, Hoffmann B, Hotzel H. Use of a novel real-time PCR technique to monitor and quantitate Mycoplasma bovis infection in cattle herds with mastitis and respiratory disease. Vet J. 2010;186:299-303.

38. Klima CL, Alexander TW, Hendrick S, McAllister TA. Characterization of Mannheimia haemolytica isolated from feedlot cattle that were healthy or treated for bovine respiratory disease. Can J Vet Res. 2014;78:38-45.

39. Liu D, Lawrence ML, Austin FW. Specific PCR identification of Pasteurella multocida based on putative transcriptional regulator genes. J Microbiol Methods. 2004;58:263-7.

40. Caporaso JG, Kuczynski J, Stombaugh J, Bittinger K, Bushman FD, Costello EK, Fierer N, Pena AG, Goodrich JK, Gordon Jl, et al. QIIME allows analysis of high-throughput community sequencing data. Nat Methods. 2010;7:335-6.

41. Wang Q, Garrity GM, Tiedje JM, Cole JR. Naïve bayesian classifier for rapid assignment of rRNA sequences into the new bacterial taxonomy. Appl Environ Microbiol. 2007;73:5261-7.

42. Glendinning L, Wright S, Pollock J, Tennant P, Collie D, McLachlan G. Variability of the Sheep Lung Microbiota. Appl Environ Microbiol. 2016;82:3225-38.

43. Epperson WB. A preliminary assessment of lung lesion distribution in fed cattle, South Dakota Beef Report, paper 4. Department of Veterinary Science, South Dakota State University, Brookings, SD.; 2003. http:// openprairie.sdstate.edu/sd_beefreport_2003/4.

44. Prohl A, Ostermann C, Lohr M, Reinhold P. The bovine lung in biomedical research: Visually guided bronchoscopy, intrabronchial inoculation and in vivo sampling techniques. J Vis Exp. 2014;89:51557. doi:10.3791/51557.

45. Zhang Z, Schwartz S, Wagner L, Miller W. A greedy algorithm for aligning DNA sequences. J Comput Biol. 2000;7:203-14.

46. Morgulis A, Coulouris G, Raytselis Y, Madden TL, Agarwala R, Schaffer AA. Database indexing for production MegaBLAST searches. Bioinformatics. 2008;24:1757-64.

47. Valarcher J-F, Bourhy H, Lavenu A, Bourges-Abella N, Roth M, Andreoletti O, Ave $P$, Schelcher F. Persistent infection of $b$ lymphocytes by bovine respiratory syncytial virus. Virology. 2001;291:55-67.

48. Bashiruddin JB, de Santis P, Persson A, Ball H, Regalla J. Detection of Mycoplasma mycoides subspecies mycoides SC in bovine lung and lymph node tissues by culture, sandwich ELISA and polymerase chain reaction systems. Res Vet Sci. 2005;78:199-205.

49. Bosio CM, Bielefeldt-Ohmann H, Belisle JT. Active suppression of the pulmonary immune response by Francisella tularensis Schu4. J Immunol. 2007;178:4538-457.

50. Rosendahl A, Bergmann S, Hammerschmidt S, Goldmann O, Medina E. Lung dendritic cells facilitate extrapulmonary bacterial dissemination during pneumococcal pneumonia. Front Cell Infect Microbiol. 2013;3:PMC3689026.

51. Beck JM, Young VB, Huffnagle GB. The microbiome of the lung. Transl Res. 2012;160:258-66.

52. Schneider M, Tait R, Busby W, Reecy J. An evaluation of bovine respiratory disease complex in feedlot cattle: Impact on performance and carcass traits using treatment records and lung lesion scores. J Anim Sci. 2009;87:1821-7.

53. Wittum TE, Woollen NE, Perino L, Littledike ET. Relationships among treatment for respiratory tract disease, pulmonary lesions evident at slaughter, and rate of weight gain in feedlot cattle. J Am Vet Med Assoc. 1996;209:814-8.

54. Gupta RS, Sethi M. Phylogeny and molecular signatures for the phylum Fusobacteria and its distinct subclades. Anaerobe. 2014;28:182-98.
55. Eribe ERK, Olsen I. Leptotrichia species in human infections. Anaerobe 2008;14:131-7.

56. Kawanami T, Fukuda K, Yatera K, Kido T, Yoshii C, Taniguchi H, Kido M. Severe pneumonia with Leptotrichia sp. detected predominantly in bronchoalveolar lavage fluid by use of 165 rRNA gene sequencing analysis. J Clin Microbiol. 2009;47:496-8.

57. Charlson ES, Diamond JM, Bittinger K, Fitzgerald AS, Yadav A, Haas AR, Bushman FD, Collman RG. Lung-enriched organisms and aberrant bacterial and fungal respiratory microbiota after lung transplant. Am J Respir Crit Care Med. 2012;186:536-45.

58. Couturier MR, Slechta ES, Goulston C, Fisher MA, Hanson KE. Leptotrichia bacteremia in patients receiving high-dose chemotherapy. J Clin Microbiol. 2012;50:1228-32.

59. Rice JA, Carrasco-Medina L, Hodgins DC, Shewen PE. Mannheimia haemolytica and bovine respiratory disease. Anim Health Res Rev. 2007:8:117-28.

60. Corbeil LB. Histophilus somni host-parasite relationships. Anim Health Res Rev. 2007;8:151-60.

61. Welsh RD, Dye LB, Payton ME, Confer AW. Isolation and antimicrobial susceptibilities of bacterial pathogens from bovine pneumonia: 1994-2002. J Vet Diagn Investig. 2004;16:426-31.

62. Allen J, Viel L, Bateman K, Rosendal S, Shewen P, Physick-Sheard P. The microbial flora of the respiratory tract in feedlot calves: associations between nasopharyngeal and bronchoalveolar lavage cultures. Can J Vet Res. 1991;55:341-6.

63. Nikunen S, Härtel H, Orro T, Neuvonen E, Tanskanen R, Kivelä SL, Sankari S, Aho P, Pyörälä S, Saloniemi H, Soveri T. Association of bovine respiratory disease with clinical status and acute phase proteins in calves. Comp Immunol Microbiol Infect Dis. 2007;30:143-51.

64. Taylor JD, Holland BP, Step DL, Payton ME, Confer AW. Nasal isolation of Mannheimia haemolytica and Pasteurella multocida as predictors of respiratory disease in shipped calves. Res Vet Sci. 2015;99:41-5.

65. Nagaraja TG, Narayanan SK, Stewart GC, Chengappa MM. Fusobacterium necrophorum infections in animals: Pathogenesis and pathogenic mechanisms. Anaerobe. 2005;11:239-46.

66. Jang SS, Hirsh DC. Characterization, distribution, and microbiological associations of Fusobacterium spp. in clinical specimens of animal origin. J Clin Microbiol. 1994;32:384-7.

67. Chirino-Trejo JM, Prescott JF. The identification and antimicrobial susceptibility of anaerobic bacteria from pneumonic cattle lungs. Can. J. Comp. Med. 1983;47:270-5.

68. Thomas A, Dizier I, Trolin A, Mainil J, Linden A, Ball H, Bell C. Isolation of Mycoplasma species from the lower respiratory tract of healthy cattle and cattle with respiratory disease in Belgium. Vet Rec. 2002;151:472-6.

69. Gagea MI, Bateman KG, Shanahan RA, van Dreumel T, McEwen BJ, Carman S, Archambault M, Caswell JL. Naturally occurring Mycoplasma bovis - associated pneumonia and polyarthritis in feedlot beef calves. J Vet Diagn Investig. 2006;18:29-40.

70. Bürki S, Frey J, Pilo P. Virulence, persistence and dissemination of Mycoplasma bovis. Vet Microbiol. 2015;179:15-22.

71. Blackburn P, Brooks C, McConnell W, Ball HJ. Isolation of Mycoplasma bovis from cattle in Northern Ireland from 1999 to 2005. Vet Rec. 2007;161:452-3.

72. Byrne WJ, McCormack R, Egan J, Brice N, Ball HJ, Markey B. Isolation of Mycoplasma bovis from bovine clinical samples in the Republic of Ireland. Vet Rec. 2001;148:331-3.

73. Gourlay RN, Howard CJ, Thomas LH, Wyld SG. Pathogenicity of some Mycoplasma and Acholeplasma species in the lungs of gnotobiotic calves. Res Vet Sci. 1979;27:233-7.

74. Miles K, McAuliffe L, Ayling RD, Nicholas RAJ. Rapid detection of Mycoplasma dispar and M. bovirhinis using allele specific polymerase chain reaction protocols. FEMS Microbiol Lett. 2004;241:103-7.

75. Larsen LE, Tegtmeier C, Pedersen E. Bovine respiratory syncytial virus (BRSV) pneumonia in beef calf herds despite vaccination. Acta Vet Scand. 2001:42:113-21.

76. Autio T, Pohjanvirta T, Holopainen R, Rikula U, Pentikäinen J, Huovilainen A, Rusanen $\mathrm{H}$, Soveri T, Sihvonen L, Pelkonen S. Etiology of respiratory disease in non-vaccinated, non-medicated calves in rearing herds. Vet Microbiol. 2007:119:256-65.

77. Zhang Y, Cui J, Parkinson A, Hayes J, Ott K, Byrum B. Isolation of Helcococcus Ovis from Sheep with Pleuritis and Bronchopneumonia. J Vet Diagn Investig. 2009;21:164-6. 
78. Post KW, Rushton SD, Billington SJ. Valvular endocarditis associated with Helcococcus ovis infection in a bovine. J Vet Diagn Investig. 2003;15:473-5.

79. Rothschild CM, Oaks JL, Schaupp JK, Rurangirwa FR, Sellon DC, Hines MT. Helcococcus ovis Isolated from a Pulmonary Abscess in a Horse. J Clin Microbiol. 2004:42:2224-6.

80. Roberts R, Carneiro M, Schatz M. The advantages of SMRT sequencing Genome Biol. 2013;14:405.

Submit your next manuscript to BioMed Central and we will help you at every step:

- We accept pre-submission inquiries

- Our selector tool helps you to find the most relevant journal

- We provide round the clock customer support

- Convenient online submission

- Thorough peer review

- Inclusion in PubMed and all major indexing services

- Maximum visibility for your research

Submit your manuscript at www.biomedcentral.com/submit 